\title{
A Novel Numerical Method for Calculating Vertical Bearing Capacity of Prestressed Pipe Piles
}

\author{
Rongbao Chen (iD, ${ }^{1,2}$ Jichao Zhang, ${ }^{1}$ Zeyu Chen, ${ }^{1}$ and Meixiang Gu ${ }^{1}$ \\ ${ }^{1}$ School of Civil Engineering, Guangzhou University, Guangzhou 510006, China \\ ${ }^{2}$ Department of Foundation Inspection, \\ Chancheng District Construction Project Quality and Safety Inspection Station of Foshan City, Foshan 528000, China
}

Correspondence should be addressed to Rongbao Chen; 1111716004@e.gzhu.edu.cn

Received 22 June 2020; Revised 13 October 2020; Accepted 28 October 2020; Published 18 November 2020

Academic Editor: Xueping Fan

Copyright (c) 2020 Rongbao Chen et al. This is an open access article distributed under the Creative Commons Attribution License, which permits unrestricted use, distribution, and reproduction in any medium, provided the original work is properly cited.

\begin{abstract}
A novel method for calculating the vertical bearing capacity of prestressed pipe piles with the acceptable error was proposed and verified. Soils at the pile side and end were, respectively, simulated by an elastic-plastic model and a new double-line (at soft rock and soil layers) or triple-line model (at hard rock and soil layers); then, a mechanical model was established for simulating vertical bearing capacity of prestressed pipe piles, and the corresponding calculation process was carried out. The values of pile side resistance, pile end resistance, and pile end elastic displacement were first obtained from the results of high-strain dynamic testing (HSDT) and then were imported into the proposed numerical model for calculating the vertical bearing capacity of prestressed concrete pipe piles. The static load test was carried out to verify the numerical results. Besides, 20 piles were tested at two typical test sites (soft and hard rock bearing strata), of which 8 piles were arranged at the soft rock bearing stratum site and 12 piles were arranged at the hard rock bearing stratum site. The numerical results achieved from an empirical formula were also used for making a comparison. The values obtained by the proposed method were highly close to those achieved from the static load test with an error of within $10 \%$. The outcomes indicated that the proposed numerical method can be potentially applied to predict the bearing capacity of prestressed pipe piles.
\end{abstract}

\section{Introduction}

In a number of countries, especially in China and Japan, prestressed concrete pipe piles have become one of the most important types of pile. The theoretical solutions employing the bearing capacity to calculate the pile shaft and tip resistance involve setbacks caused by uncertainty factors, such as installation method, stress history, and soil compressibility [1]. The experimental tests, such as standard penetration test (SPT), static cone penetration test (CPT), and static load test (SLT), correlating results of in situ tests with the bearing capacity of pile, are frequently used in evaluating load-bearing capacity of a single pile; note they also involve shortcomings induced by both operator and test procedure [2]. According to the specification, the blow count $(\mathrm{N})$ of SPT (SPT-N), the number of blows to drive a sampler
$300 \mathrm{~mm}$ in the ground, may significantly vary due to the various experimental and operational conditions in the preliminary investigation of a project site [3], and the SPT-N is widely applied in predicting bearing capacity and assessing the quantificational risk of soil liquefaction [3-5]. For CPT, it is taken as one of the most significant field tests into account for the soil characterizations because CPT is a robust, simple, fast, reliable, and economical test, providing continuous soundings of subsurface soil and does not require extensive coring [6]. Generally, CPT is advantageous in the study of geotechnical behavior of a pile due to the resemblance between the cone penetrometer and pile, which consequently has extensive applications in geotechnical engineering [7]. Cone-tip resistance and sleeve friction are measured and recorded simultaneously when the tip penetrates the soil layer [8]. After acquiring the cone penetration 
data, there are two approaches to apply CPT records for both drilled and driven piles' design $[7,8]$. One is a direct approach, in which the measured cone-tip resistance and sleeve friction are directly used for calculating the bearing capacity of a pile [9-16], while the other is an indirect approach, in which the measured CPT data are applied first to estimate soil parameters. Then, the estimated data are used to obtain the end-bearing capacity, as well as the unit skin friction $[17,18]$. Moreover, a CPTu-based enhanced unicorn method for pile capacity has been proposed, which could estimate axial pile capacity for a wide variety of types of piles installed in different assortments of geomaterials [19].

High-strain dynamic testing (HSDT) of piles [20], based on one-dimensional wave propagation, is an innovative method in predicting the bearing capacity of buried piles, and the bearing capacity has been proved to be in close agreement with that of SLT [21]. Xu and Li [22] conducted experimental study and theoretical analysis on the vertical bearing capacity of pipe piles. They combined a large amount of data for a pipe pile foundation project with the measured displacements at the top and bottom of piles under a SLT to determine the mechanical characteristics of pile endbearing layer and revised a formula used for calculating the axial force of pile end. Zhang et al. [23] carried out a series of SLTs to analyze the load-displacement relationship, friction resistance, and pile end resistance. They used a simple model to describe the degradation of pile side resistance and pile end load-displacement relationship at the pile-soil interface. Their results showed that in the nondestructive load testing, the pile side resistance softening only occurred in shallow soil, and the pile side resistance in deep soil was not fully realized. However, in the destructive load testing, the pile side resistance softening occurred across the whole pile-soil interface. They further studied the relationship between the pile side resistance and the relative displacement of pile and soil, as well as the relationship between pile end resistance and pile end displacement to establish a load-displacement model [24].

The pile properties are also of considerable significance to better evaluate the bearing capacity of the pile foundation. A new type of offshore oil and gas platform mixed pile was explored with the laboratory test program and the FEM, and the results show that the novel offshore foundation type is suitable for a wide range of sand conditions [25]. The influences of sand piles on improving the bearing capacity of soil foundations as well as controlling the settlement have been studied by partially replacing sand piles with constraints [26]. Moreover, there are still several factors affecting the bearing capacity of the pile foundations, such as external sulfate attack, effective radius, and the elastic modulus of a pile. The degree of soil-plugging should be considered when the bearing capacity of the open-ended pile is studied [27]. The plugging effect of open-ended piles is highly influenced by the pile driving condition, soil condition, and pile geometry [28]. The vertical bearing capacity of prestressed pipe piles generally depends on the soil parameters and soil-pipe interaction. As the soil surrounded a pile is multilayered and heterogeneous, it is complicated to calculate the vertical bearing capacity of the prestressed pipe pile in different layers of soil. It is noteworthy that the calculation involves a series of parameters that include pile side resistance, pile end resistance, pile side elastic displacement, pile end elastic displacement, pile length, pile area, and elasticity modulus of pile.

Considering the high cost of in situ tests, artificial intelligence (AI), combined with mathematics, algorithm, and creativity, has been introduced to establish AI-based predictive models for estimating bearing capacity of piles [29-34]. Using the results of CPT, two artificial neural networks (ANNs) and a nonlinear multiple regression model for predicting pile resistance were developed to predict pile resistance. It has been proved that the application of AI and predictive models can be practical, feasible, and they are regarded as fast tools in solving engineering problems [35]. Apart from that, a new on-site camera method based on node displacement with the biological mechanism of phagocytosis to correlate continuous images was developed to calculate the settlement of piles [36]. In addition to in situ tests, numerical simulation methods have also been applied to study the bearing capacity of piles. Chen et al. used a discrete element model (DEM) to assess the pilesand interactions at the microscale [37]. Cai et al. utilized a finite element model (FEM) to calculate the bearing capacity at the tip of the pile for different slope angles [38]. Józefiak et al. also adopted the FEM to obtain the pile bearing capacity and pile settlement of the soil-pile system [39]. For a broad group pile foundation, the field load tests combined with numerical analyses are typically applied to estimate the ultimate performance of the pile foundation [40].

Recently, a number of scholars concentrated on the dynamic testing of piles based on stress wave theory. Liang and Yang [41] developed reliability-based quality control criteria for driven piles based on the framework of acceptance-sampling analysis for both static and dynamic testing methods with the lognormal distribution characteristics. They also suggested an optimum approach for the number of load tests and the required measured capacities for quality control of driven piles. Salgado et al. [42] proposed an advanced model for dynamic pile driving analysis to develop accurate pile driving formulas. Comparisons of predictions from the proposed formulas with results from static and dynamic load tests showed that reasonably accurate predictions of pile capacity could be achieved. The HSDT has several advantages in pile analysis, while it cannot fully simulate the bearing capacity of end-bearing piles when the bearing capacity of end-bearing piles is tested [43].

In this research, a novel method for calculating the vertical bearing capacity of prestressed pipe piles is proposed via establishing a new mechanical model numerically. The mechanical parameters, such as pile side resistance, pile end resistance, and pile end displacement, are obtained by HSDT and then are imported into a new mechanical model. To verify the accuracy of the numerical method, 20 test piles are arranged in two typical test sites, and their mechanical properties are tested. The novel numerical method can improve the design efficiency and reduce the engineering cost, and it can be potentially applied to design prestressed pipe piles. 


\section{Establishment of a Novel Mechanical Model}

2.1. Analytical Modeling of a Pile. In order to model a pile analytically, the prestressed concrete pipe piles are theoretically divided into a series of elements with uniform length and diameter (Figure 1). The axes of each element are assumed to be straight lines, and the angle between the axis and the horizontal plane is denoted by $\alpha$. For any node located on an element, the static equilibrium equation is formulated as follows [44]:

$$
\mathbf{P}=\mathbf{A F},
$$

where $P$ is an external force at joints (including force and bending moment), $A$ represents a coefficient matrix, and $F$ is an internal force of the pile at joints (including force and bending moment).

$X$ is defined as a displacement matrix of nodes relative to the original axis of a pile under external forces and $e$ as a displacement matrix of the internal force. As a result, the following equation is given:

$$
e=B X
$$

According to previous studies $[45,46], B$ is the transpose of matrix $A(B=\mathrm{AT})$. Therefore, equation (2) can be rewritten as

$$
e=A^{T} X
$$

We assume that the internal force $F$ in each element has the following relationship with its corresponding internal displacement $e$ :

$$
\left.\begin{array}{l}
F=\operatorname{Se}, \\
F=S A^{T} X, \\
P=A S A^{T} X, \\
X=\left[A S A^{T}\right]^{-1} P .
\end{array}\right\}
$$

A local coordinate system for each element $i$ is established to construct the coefficient matrix $A_{i}$ and stiffness matrix $S_{i}$. Then, the matrices given by $S A^{T}$ and $A S A^{T}$ are constructed for each element, and the total matrix $A S A^{T}$ in the global coordinate is formed by superposition, i.e., the total stiffness matrix. Based on the total stiffness matrix, the incremental values of internal forces and the displacement of the pile under load are obtained. Thus, the total internal force and the displacement of each node in the pile elements can be obtained by superposing the results calculated with the initial internal force and displacement at each node of the pile. It is noteworthy that the theoretically developed model can be used to analyze the bearing capacity of vertical or inclined piles under the combined actions of horizontal load, vertical load, and bending moment [47].

The lateral soil resistance was simulated by adding a lateral soil spring at each node of the pile, and the load transfer function of pile side was used to analyze the relationship between the unit side resistance and the pile-soil relative displacement. For the unit side resistance, it is related to the ultimate resistance and elastic displacement of the pile side. The pile end soil resistance was simulated by adding a vertical soil spring at the pile end, and the load transfer function at the pile end was employed to analyze the relationship between the unit end resistance and the pile end displacement. For the unit end resistance (spring coefficient), it is related to the ultimate resistance at the pile end and the elastic limit displacement at the pile end.

\subsection{Presentation of a Load Transfer Function for Pile Side} Resistance and Parameters of Piles. An elastic-plastic doublefolded line model [48] has been widely used in analysis of pile side resistance because of its simplicity and accuracy in calculation $[47,49]$. It was thus employed in this paper for establishing a load transfer function at the pile side. With the application of HSDT for test piles, a fully excited pile side resistance was used as the limit value of the pile side resistance.

A load transfer function of the pile side is presented in equation (5), and the load transfer function of the pile side is shown in Figure 2.

$$
q(s)= \begin{cases}c_{\mathrm{s}} s, & \left(s \leq s_{\mathrm{u}}\right), \\ q_{\mathrm{u}}, & \left(s>s_{\mathrm{u}}\right),\end{cases}
$$

where $c_{\mathrm{s}}$ is the pile side resistance per unit displacement in elastic soil, $q_{\mathrm{u}}$ denotes the design value of pile side resistance achieved according to the results of HSDT, and $s_{\mathrm{u}}$ denotes the relative displacement between pile and soil when the pile side resistance reaches the limit value.

In the present research, $s_{\mathrm{u}}$ is determined using Table 1, where the empirically determined values of relative displacement corresponding to the maximum lateral resistance values of rock and soil layers are presented when the bearing capacity of prestressed concrete pipe piles is calculated. Expectedly, the relative displacement of rock stratum required to reach the limit value is less than that of the soil layer.

\subsection{Presentation of a Load Transfer Function for Pile End} Resistance and Parameters of Piles. At present, twofold load transfer functions and threefold load transfer functions are mainly used in formulating load transfer functions for pile end resistance. For instance, Zhang et al. [24] explored the relationship between pile end resistance and its displacement and developed a twofold load transfer function. Luo and $\mathrm{Li}$ [50] theoretically analyzed the bearing capacity of piles to develop a unified threefold load transfer function with consideration of the elastic, plastic, and sliding stages of the pile end, and they also formulated an analytical solution. In the abovementioned functions, the displacement at the beginning of pile loading is generally proportional to the load magnitude. However, when the displacement is greater than the elastic limit displacement at the end of the pile, the displacement at the end of the pile may change abruptly after the pile is reloaded. The end resistance is also influenced by the degree of softness and hardness of the rock strata and soil layers at the end of the pile. 

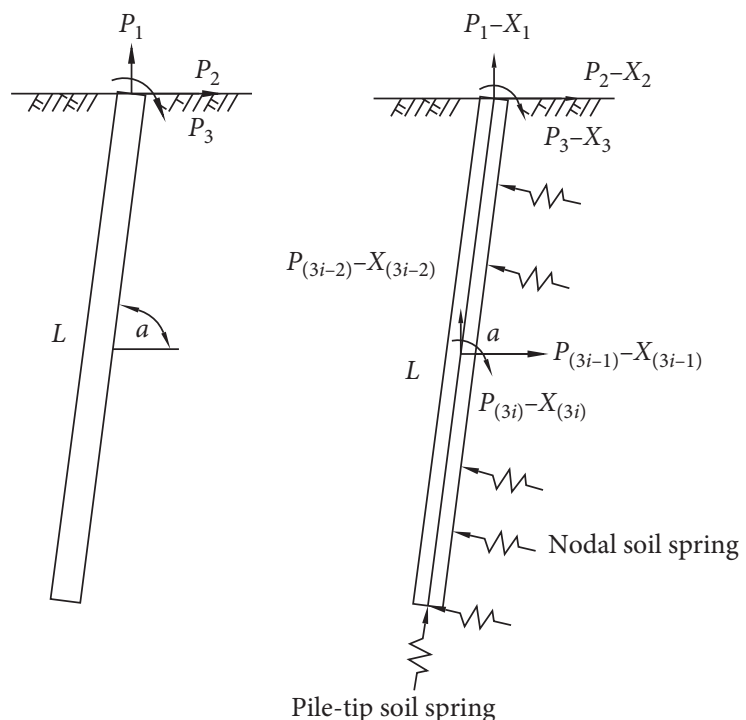

(a)

(b)
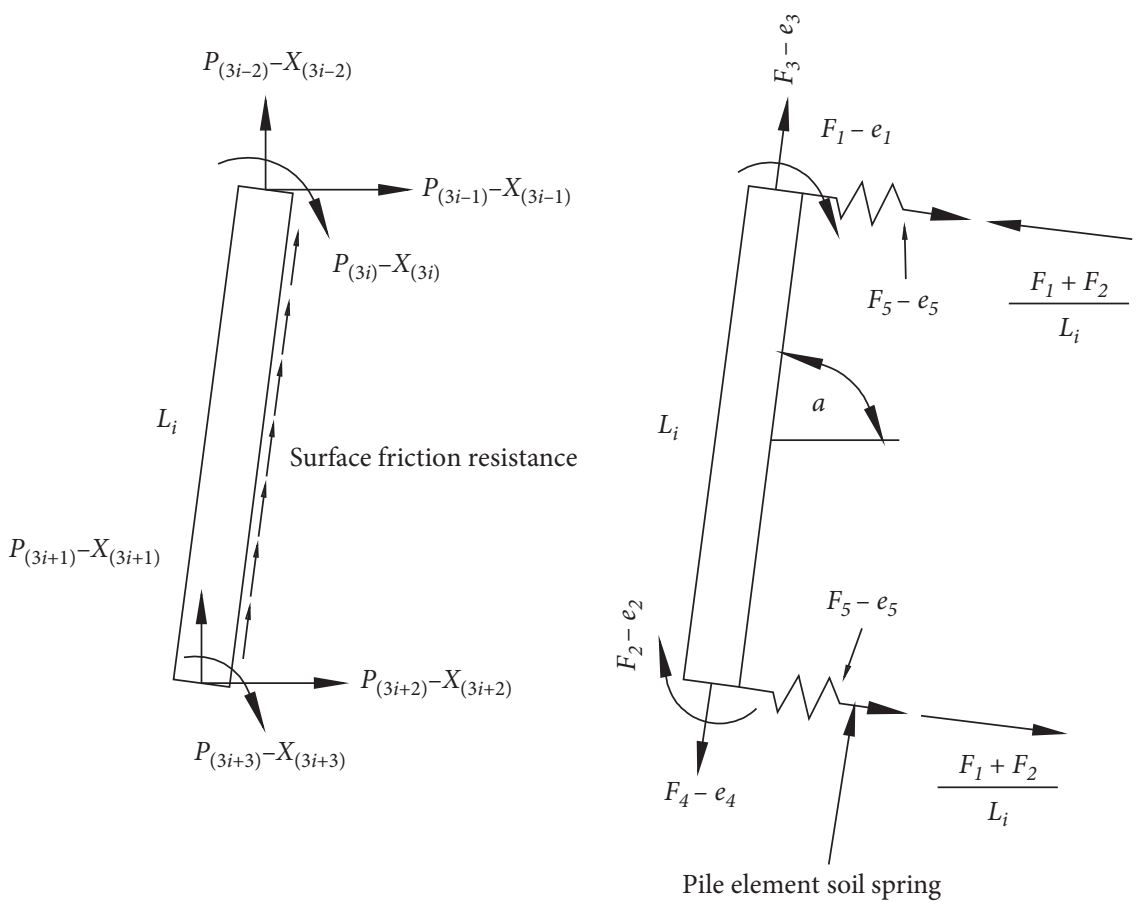

(c)

Figure 1: Schematic diagram of coding of pile elements. (a) Pile. (b) Analytical model of the pile. (c) $P$-X and F-e coding.

Hence, in this research, a new load transfer function is proposed, and two mechanical models are established according to the soft/hard rock and soil layers at the end of the pile.

2.3.1. Soft Rock and Soil Layers. The proportion of load that was borne by pile lateral friction and pile end resistance in soft soil is small due to the shear failure behavior at the end of the pile. Q-S curve (Figure 3) shows a steep drop, and damages at characteristic points are evident. A new load transfer function is utilized at the end of pile (equation (6)). Figure 4 illustrates utilization of the load transfer function at the end of pile.where

$$
\begin{aligned}
& k_{1}=\frac{R_{\mathrm{c}}}{s_{\mathrm{c}}}, \\
& k_{2}=\eta k_{1},
\end{aligned}
$$

where $k_{1}$ is the spring coefficient at the end of pile; $R_{\mathrm{c}}$ denotes the pile end resistance obtained from the HSDT; $s_{c}$ 


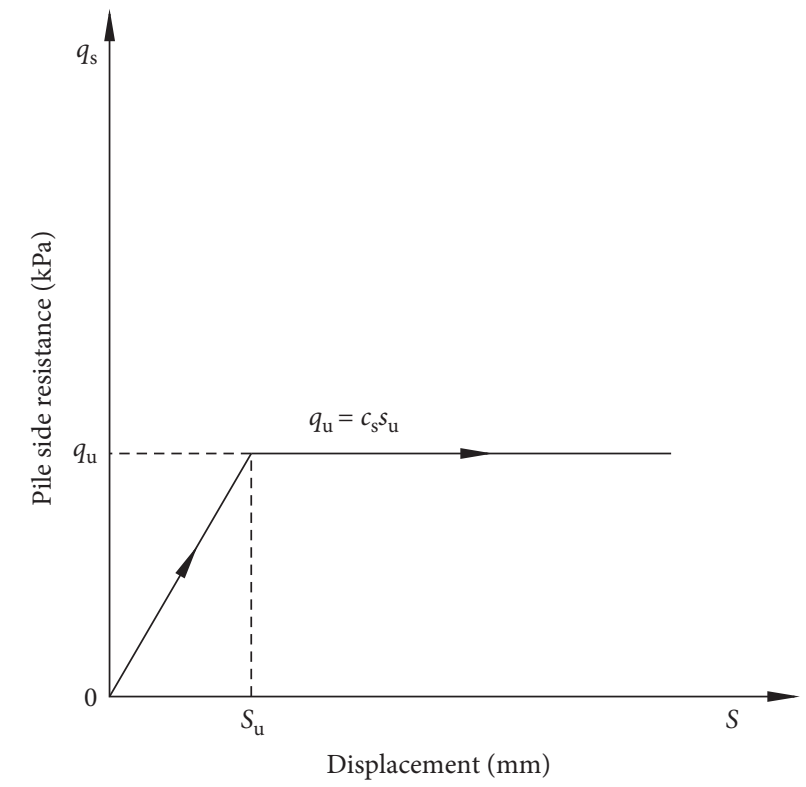

Figure 2: Illustration of the load transfer function at the pile side.

TABLE 1: Relative displacement $s_{\mathrm{u}}$ at the maximum shaft resistance.

\begin{tabular}{lcccccc}
\hline Soil layer & Filler & Muddy clay & Cohesive soil & Silty soil & Sandy soil & Weathered rock soil \\
\hline$s_{\mathrm{u}}(\mathrm{mm})$ & $7-10$ & $7-12$ & $6-10$ & $6-10$ & $5-9$ & $3-7$ \\
\hline
\end{tabular}

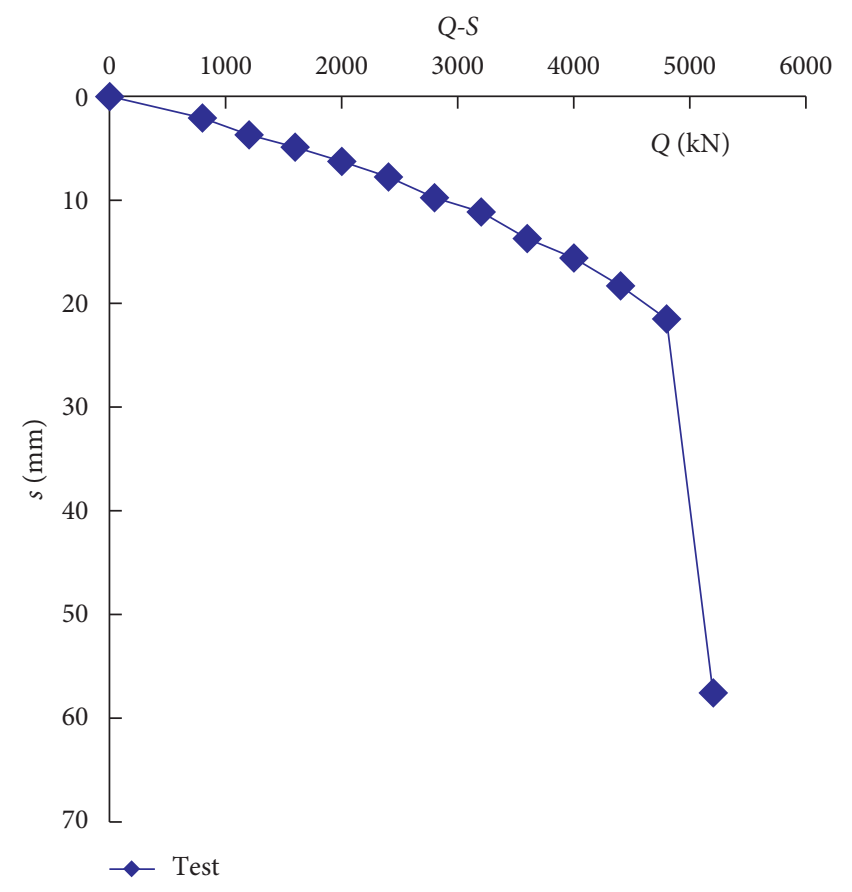

Figure 3: Q-S curve.

represents the pile end displacement obtained from the HSDT; $s_{\text {bu }}$ is the ultimate displacement at the end of pile; and $\eta$ indicates the reduction coefficient of spring at the end of the pile, generally ranging from 0.2 to 0.4 .

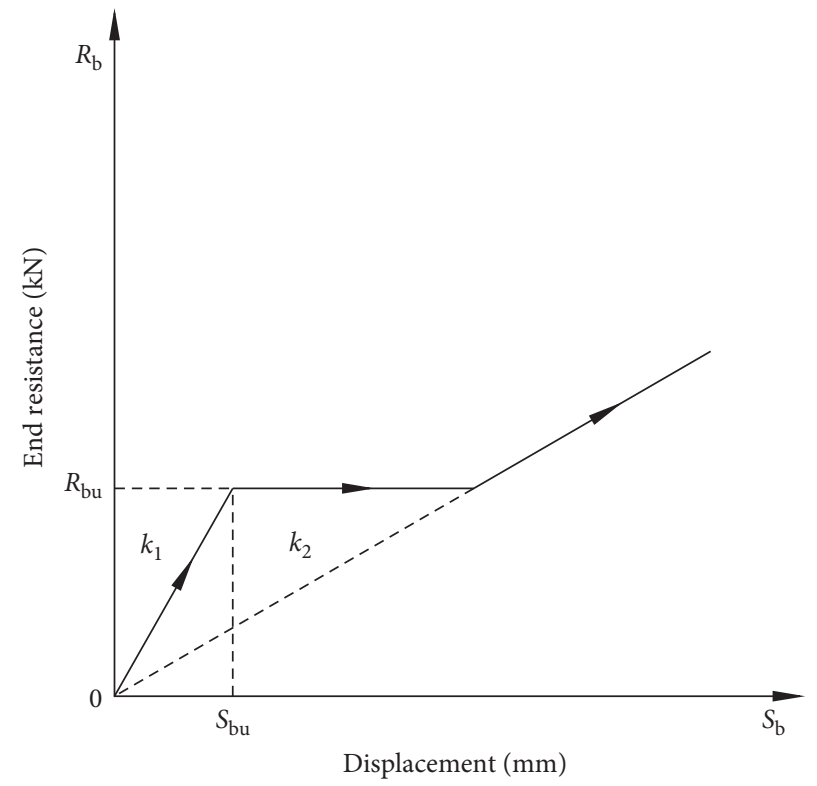

FIgURE 4: Illustration of load transfer function at the end of a pile.

$$
R(s)= \begin{cases}k_{1} s_{\mathrm{b}}, & \left(s_{\mathrm{b}} \leq s_{\mathrm{bu}}\right) \\ k_{2} s_{\mathrm{b}}, & \left(s_{\mathrm{b}}>s_{\mathrm{bu}}\right)\end{cases}
$$

Several scholars proposed different methods for obtaining $s_{\text {bu }}$. For instance, a number of scholars [51] studied 
the bearing capacity using HSDT with sufficient excitation of pile end resistance. It was found that pile end displacement was $2.5 \%$ of the pile diameter when the pile end resistance was fully excited. Zhang et al. [23] conducted SLTs to study the relationship between pile end resistance and pile end displacement and attempted to formulate a robust loaddisplacement relationship. They found that the ultimate displacement in the first stage of a fully excited pile end was $0.5-8.3 \mathrm{~mm}$.

2.3.2. Hard Rock and Soil Layers. For hard rock and soil layers with high end resistance and those requiring a large displacement to exert end resistance, the $Q-S$ curve (Figure 5) displays that damages in characteristic points are not evident. A new load transfer function was developed for the end of pile in this research (equation (8)). Figure 6 shows the Q-S curve based on the load transfer function at the end of pile.where

$$
\begin{aligned}
& k_{1}=\frac{R_{\mathrm{c}}}{s_{\mathrm{c}}}, \\
& k_{2}=\eta_{2} k_{1}, \\
& k_{3}=\eta_{3} k_{1},
\end{aligned}
$$

where $k_{1}$ represents spring coefficient at the end of pile; $R_{\mathrm{c}}$ is the pile end resistance obtained from the HSDT; $s_{\mathrm{c}}$ denotes the pile end displacement achieved from the HSDT; $s_{\text {bul }}$ is the first-stage limit displacement at the end of pile; $s_{\text {bu2 }}$ indicates the second-stage limit displacement at the end of pile; $\eta_{2}$ represents the second-stage reduction coefficient of spring at the end of pile, generally ranging from 0.4 to 0.8 ; and $\eta_{3}$ is the third-stage reduction coefficient of spring at the end of pile (range, $0.2-0.4$ ).

$$
R(s)= \begin{cases}k_{1} s_{\mathrm{b}}, & \left(s_{\mathrm{b}} \leq s_{\mathrm{bu} 1}\right), \\ k_{2} s_{\mathrm{b}}, & \left(s_{\mathrm{bu} 1}<s_{\mathrm{b}} \leq s_{\mathrm{bu} 2}\right), \\ k_{3} s_{\mathrm{b}}, & \left(s_{\mathrm{b}}>s_{\mathrm{bu} 2}\right),\end{cases}
$$

\section{Development of Numerical Models}

The proposed numerical models were programmed by FORTRAN. The flowchart of algorithm development is depicted in Figure 7, and the input parameters are summarized in Table 2. The limit value of pile side resistance was measured by HSDT. The spring coefficient at the end of pile could be achieved by calculating the resistance and displacement at the end of pile via testing pile and then fitting a high stress-strain curve. The results of algorithm development could be achieved and then verified by the field testing data.

\section{Experiments}

As the softness and hardness of a rock stratum can influence the characteristics of piles in the Q-S curve, both soft rock

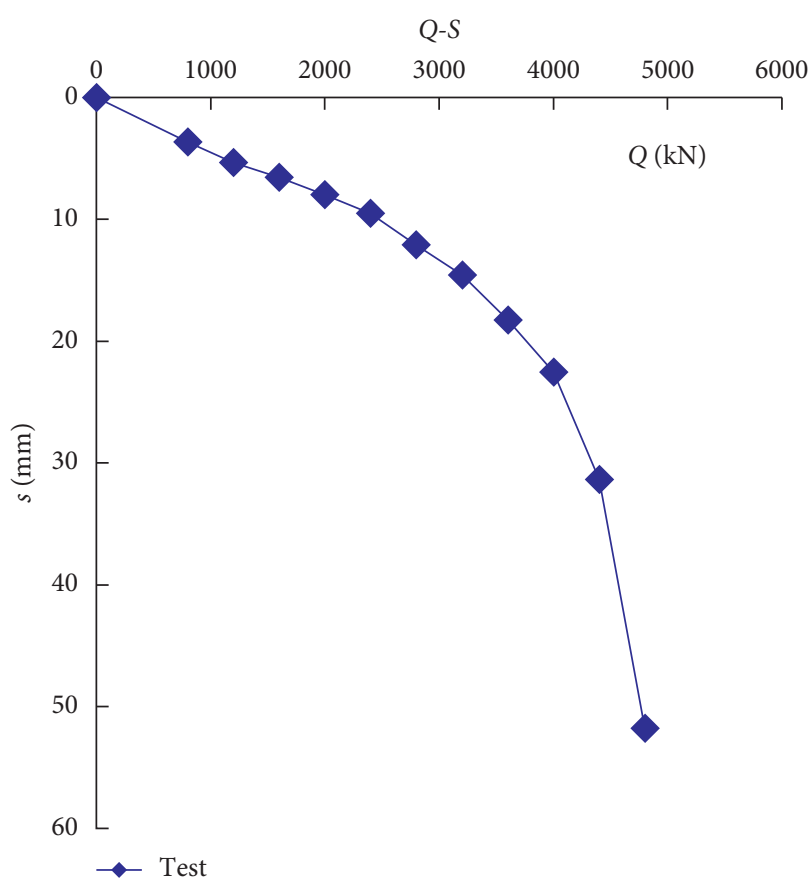

Figure 5: Q-S curve.

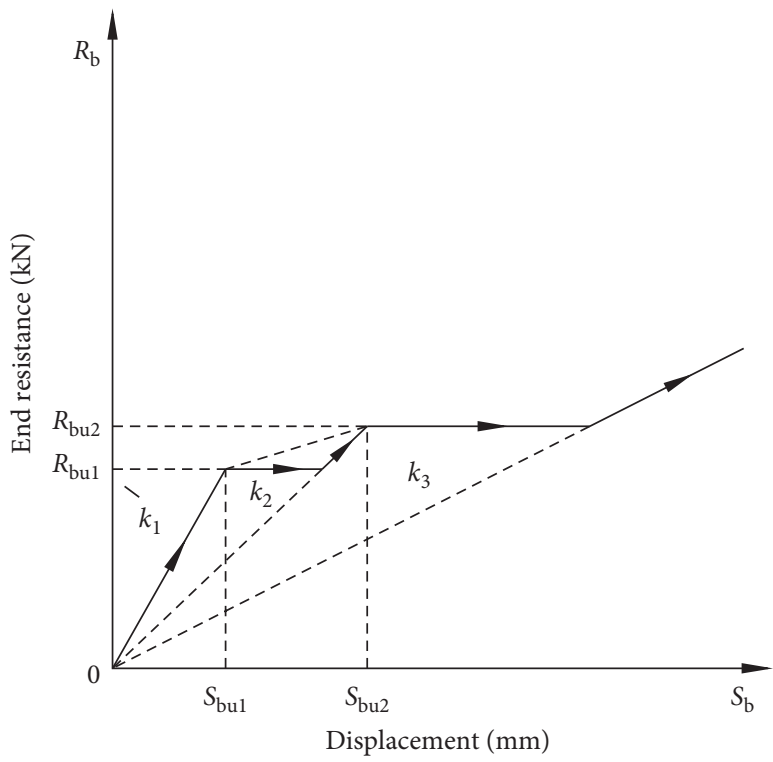

FIGURE 6: Illustration of load transfer function at the end of a slowly changing pile.

bearing stratum and hard rock bearing stratum were selected as sites for testing of piles in the present research. A highly weathered mudstone was considered as a soft rock bearing stratum, and a highly weathered argillaceous siltstone was taken as a hard rock bearing stratum into account.

\subsection{Testing of Piles}

4.1.1. Overview of the Test Sites. Herein, 8 high-strength prestressed concrete pipe piles were arranged on the soft 


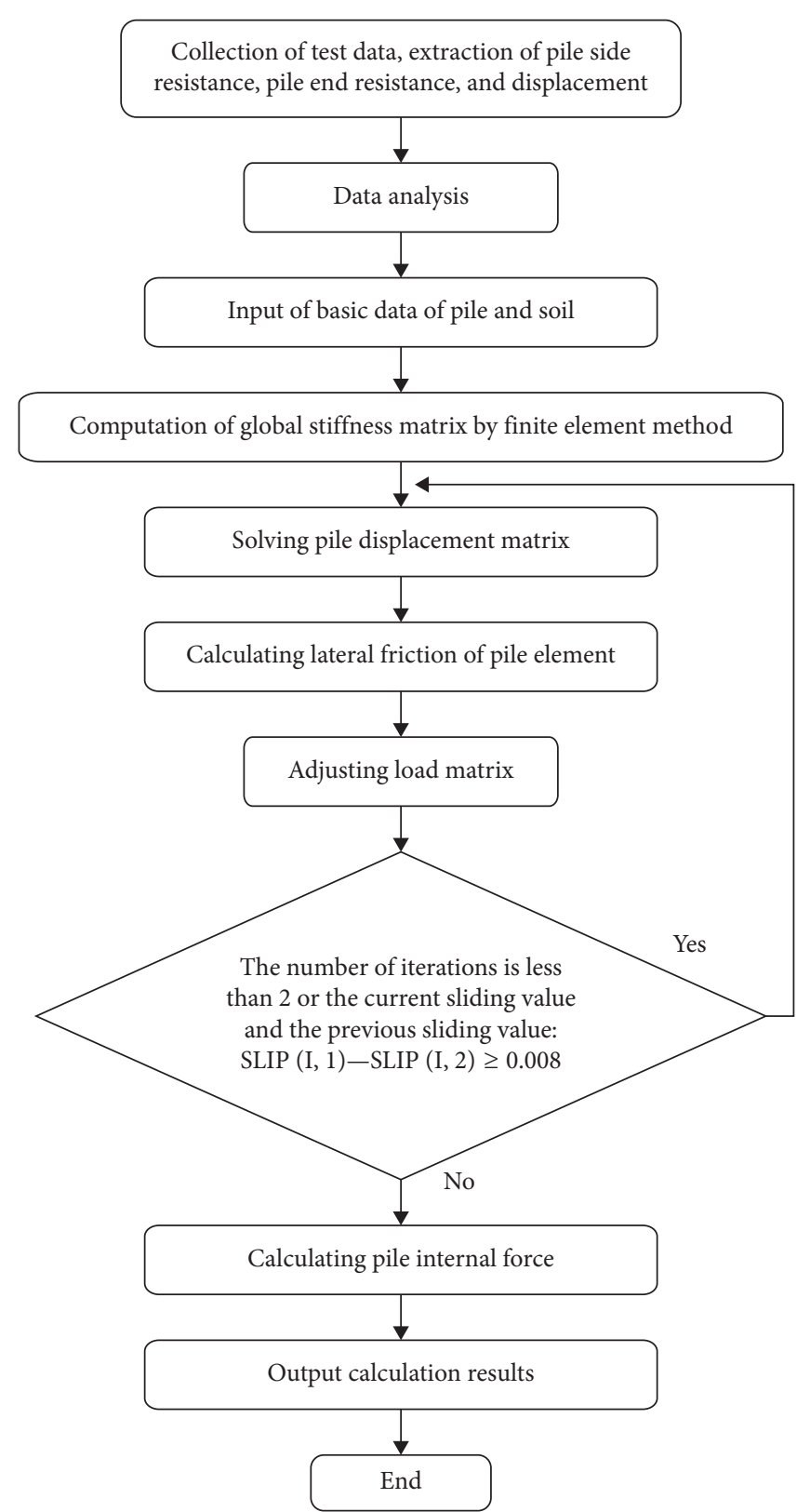

FIGURE 7: The algorithm proposed for calculating vertical bearing capacity of prestressed concrete pipe piles.

TABle 2: Parameters calculated via the proposed algorithm.

NP (load number), NM (element number), NNZP (number of nonzero loads), NC (number of load-transfer curves), IPRD (switches 1 with known loads are started if the loads are $>0$ ), JTSOIL (nodes at the beginning of the soil surface), LIST (output information), and NSTRPT (number of points on the shear-transfer curve)

E (modulus of elasticity), PIL (pile length), POINTK (pile end spring coefficient), AREAP (area of pile end), ALPHA (inclination of the

2 pile to horizontal line), POINTX (displacement of pile end), and XMAX (maximum pile end displacement)

3 I (number of nonzero loads to read in), P (I) (load corresponding to I)

NEC (JJ) (number of segments corresponding to each set of load-transfer data)

$4 \mathrm{X}$ (relative displacement of pile and soil)

$\mathrm{Y}$ (shear force)

5 XL (I) (unit length of pile), XIN (I) (element moment of inertia), BMEM (I) (element width), PER (I) (element circumference), and 5 AREA (I) (element area) 
rock bearing stratum site, of which 6 were made of $\phi 500$ (wall thickness, $125 \mathrm{~mm}$ ) and 2 were made of $\phi 400$ (wall thickness, $95 \mathrm{~mm}$ ); the length of the piles was $23-25 \mathrm{~m}$, and the distance between the piles was $7.5 \mathrm{~m}$. Sliding micrometers were preembedded into 4 piles $(\phi 500)$ at this site. In addition, 12 high-strength prestressed concrete pipe piles were arranged on the hard rock bearing stratum site, of which 10 were made of $\phi 500$ (wall thickness, $125 \mathrm{~mm}$ ) and 2 were made of $\phi 400$ (wall thickness, $95 \mathrm{~mm}$ ); the length of the piles was $22-26 \mathrm{~m}$, and the distance between the piles was $8.0 \mathrm{~m}$. Each test pile consisted of two conjoined pile sections. Besides, 4 piles $(\phi 500)$ at this site contained sliding micrometers.

A geological survey was carried out adjacent to each test pile. The center of the drilling hole was $0.8 \mathrm{~m}$ away from the center of the pile hole. The test piles containing the preembedded sliding micrometers were selected to assess the distribution and proportion of friction and the end resistance under various loads, the exertion of friction in different strata, the settlement at the end of pile, and the total compressive deformation of the pile. The field test sites are displayed in Figure 8, and the detailed parameters of each test pile are listed in Tables 3 and 4 .

4.1.2. Results of Testing of Piles. The results of testing of 6 prestressed pipe piles made of $\phi 500$ (piles no. 1, 2, 3, 4, 5, and 6 ) at the soft rock bearing stratum site and those of 9 prestressed pipe piles made of $\phi 500$ (piles no. 1, 2, 3, 4, 7, 8, 10,11 , and 12) at the hard rock bearing stratum site were statistically analyzed. It should be noted that pile \#5 failed in the field test, and, thus, its data were not presented.

The pile side resistance was obtained based on the results of HSDT and measurements of sliding micrometers. The average pile side resistance for each soil layer is shown in Tables 5 and 6 . The resistance and elastic limit displacement of soil at the end of the pile were obtained from the results of HSDT. The resistance, elastic limit displacement, and spring coefficient of soil at the end of each test pile are presented in Tables 7 and 8 . The results of the test piles $(\phi 500)$ at the soft (hard) rock bearing stratum site showed that the elastic limit displacement at the end of the pile was $6.9-11.5 \mathrm{~mm}$ $(7.4-14.4 \mathrm{~mm})$, and the spring coefficient at the end of the pile was $83-282 \mathrm{kN} / \mathrm{mm}(200-420 \mathrm{kN} / \mathrm{mm})$. The lateral resistance, end resistance, and distribution ratio of four piles $(\phi 500)$ tested with the preembedded sliding micrometers are summarized in Tables 9 and 10. These results are obtained from the measurements and fitting results of HSDT of piles on the soft rock bearing stratum site and hard one, as shown in Figures 9(a)-10(d), respectively. The curves of the sliding micrometer related to piles at the soft rock bearing stratum site and hard one are illustrated in Figures 11(a)-12(d), respectively. To explain the principle of HSDT that was employed in this research and the results that are presented in Figures 9(a)-10(d), the analysis of pile \#1 in Figure 9(a) is taken as an example. The satisfactory agreement between solid line and dashed line (top-left corner subfigure in Figure 9(a)) indicates acceptable results of field testing. The solid line represents the results of field testing, and the dashed line shows the results of numerical simulation. The top-right corner subfigure in Figure 9(a) illustrates the excitation profiles at the end of pile. The bottom-left corner subfigure in Figure 9(a) displays the pile top displacements. The calculated values of pile side and pile end resistance could be obtained from the bottom-right corner subfigure in Figure 9(a).

4.1.3. Analysis of Test Piles. Four test piles $(\phi 500)$ that were buried with a preembedded sliding micrometer at both soft and hard rock bearing stratum sites were mechanically simulated, and a numerical algorithm was developed. Four test piles at each site were modeled using the following parameters. The Sato elastic-plastic twofold line model [45] was used for transferring load into the pile side. The ultimate resistance of the pile side was measured by HSDT (Tables 5 and 6). The ultimate displacement $s_{\mathrm{u}}$ of the pile side was determined according to the results of systematic testing. The values of the ultimate displacement $s_{\mathrm{u}}$ of the pile side in each soil layer are presented in Table 1.

Equations (6) and (8) were used for load transfer at the pile end at the soft rock bearing stratum site and hard one, respectively. The corresponding average values of the spring coefficient $k_{1}$ were 166 and $290 \mathrm{kN} / \mathrm{mm}$, respectively, on the basis of the results of HSDT (Tables 7 and 8).

The reduction coefficient $\eta$ of the spring at the end of the pile on the soft rock bearing stratum site was 0.25 , while on the hard rock bearing stratum site, the values of the reduction coefficient of the spring at the pile end were 0.80 (in the second stage) and 0.25 (in the third stage), respectively.

Tables 7 and 8 show that the elastic limit displacement of the pile end ranges from 6.9 to $11.5 \mathrm{~mm}$ with an average value of $8.7 \mathrm{~mm}$ (at soft rock bearing stratum site) and from 7.4 to $14.4 \mathrm{~mm}$ with an average value of $10.6 \mathrm{~mm}$ (at hard rock bearing stratum site).

In the present study, for piles at the soft rock bearing stratum site, the ultimate displacement $s_{\mathrm{bu}}$ of the pile end was the elastic limit displacement of the pile end given by the results of HSDT, and the model predicted the elastic limit displacement of the pile end to be equal to $8.5 \mathrm{~mm}$. For the hard rock bearing stratum site, the limit displacement $s_{\text {bu2 }}$ of the pile end for the second stage corresponding to the elastic limit displacement of the pile end could be achieved by the results of HSDT $(10.5 \mathrm{~mm})$. The ultimate displacement $s_{\text {bul }}$ of the pile end for the first stage was within $1.5-2.0 \mathrm{~mm}$ that was smaller than that for the second stage. The predicted ultimate displacement $s_{\text {bu1 }}$ for the first stage at the pile end was $9.0 \mathrm{~mm}$. The results of numerical simulation and SLTs of four test piles at each site are depicted in Figures 13(a)14(d).

4.1.4. Comparing the Results of Numerical Simulation and Experimental Testing. Tables 11 and 12 show the ultimate vertical bearing capacity and the differences between the four methods at both sites. To compare the differences between different methods with the SLTs, the corresponding values were normalized to values of the SLTs (Figure 15). 


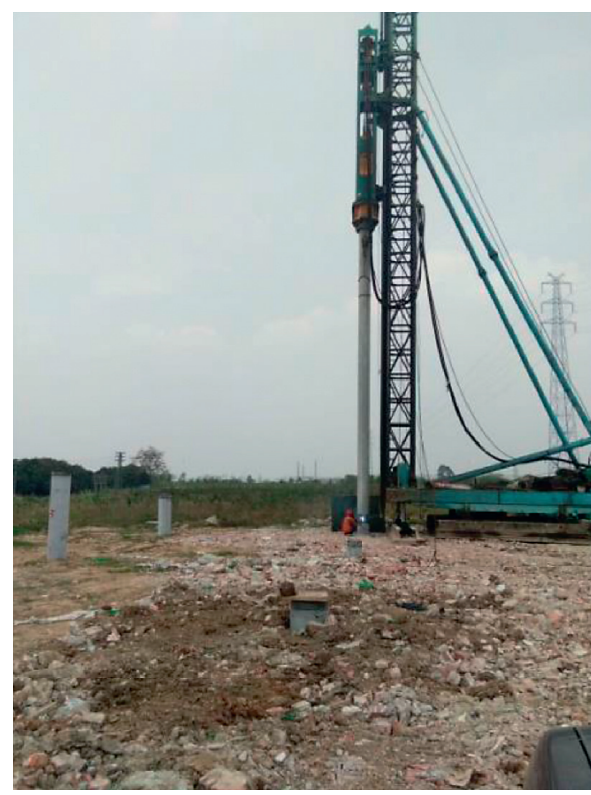

(a)

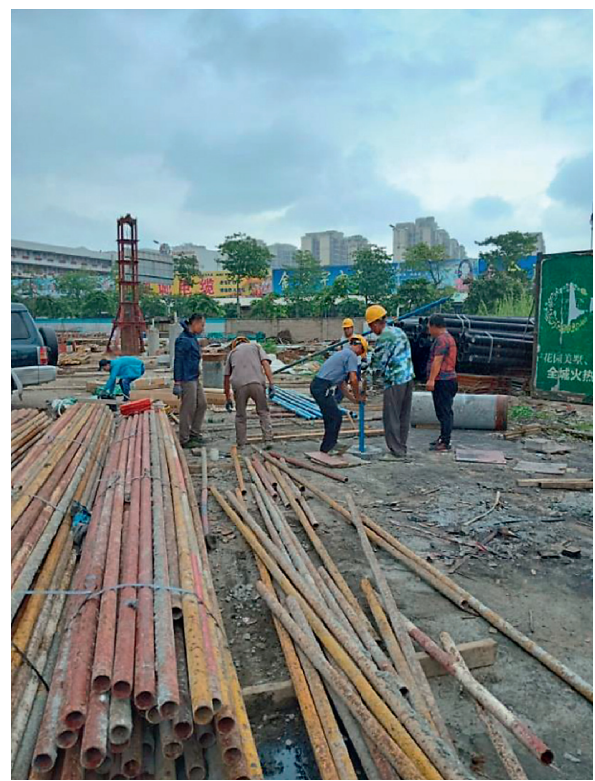

(c)

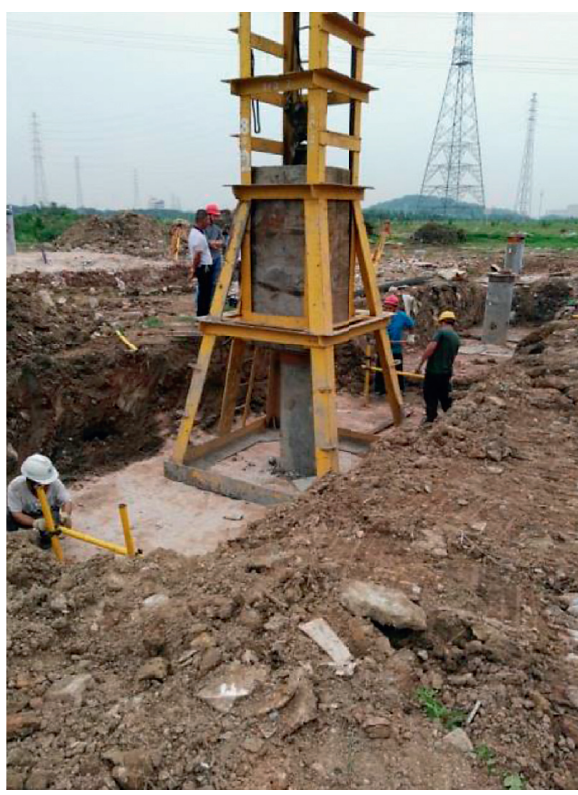

(b)

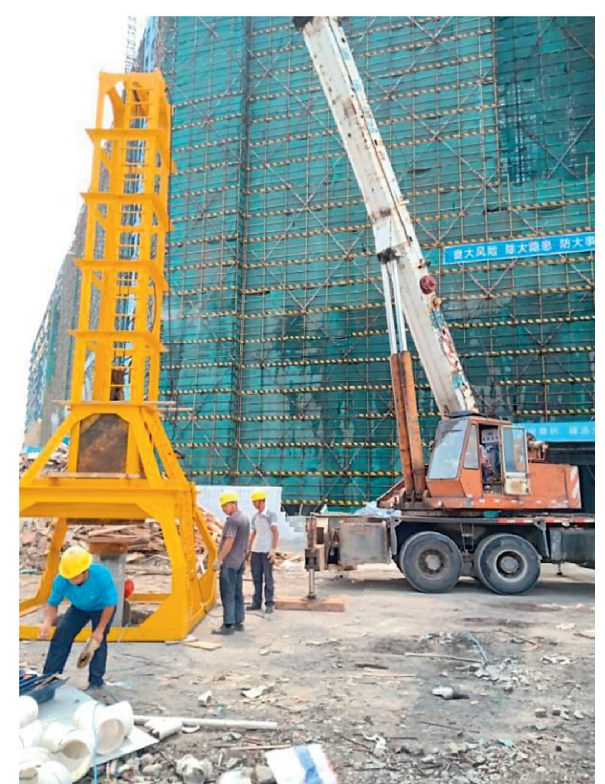

(d)

Figure 8: Field tests at soft rock bearing stratum (a) and (b) and at hard rock bearing stratum (c) and (d). (a) Pile driving (soft rock bearing stratum). (b) High-strain testing (soft rock bearing stratum). (c) Installation of sliding micrometers (hard rock bearing stratum). (d) Highstrain testing (hard rock bearing stratum).

TABLE 3: Characteristics of test piles at the soft rock bearing stratum site.

\begin{tabular}{lcccccccc}
\hline Pile no. & 1 & 2 & 3 & 4 & 5 & 6 & 7 & 8 \\
\hline Diameter $(\mathrm{mm})$ & $\phi 500$ & $\phi 500$ & $\phi 500$ & $\phi 500$ & $\phi 500$ & $\phi 500$ & $\phi 400$ & $\phi 400$ \\
Length $(\mathrm{m})$ & 22.90 & 23.00 & 23.60 & 25.00 & 25.00 & 25.00 & 24.80 & 25.00 \\
Underground length $(\mathrm{m})$ & 22.85 & 23.00 & 23.57 & 24.20 & 23.50 & 23.78 & 24.80 & 24.25 \\
Embedment depth of pile into rock $(\mathrm{m})$ & 0.75 & 0.90 & 1.17 & 1.50 & 1.40 & 1.08 & 0.90 & 1.45 \\
Grade of concrete strength & $\mathrm{C} 80$ & $\mathrm{C} 80$ & $\mathrm{C} 80$ & $\mathrm{C} 80$ & $\mathrm{C} 80$ & $\mathrm{C} 80$ & $\mathrm{C} 80$ & $\mathrm{C} 80$ \\
\hline
\end{tabular}

The results of comparison showed that the values of numerical simulation and experimental testing were approximately in agreement at both sites. For instance, for piles at the soft (hard) rock bearing stratum site, the differences between the results of HSDT and the SLTs for the 4 test piles were $10.5 \%(4.2 \%),-3.4 \%(14.6 \%),-4.0 \%(-13.9 \%)$, and 
TABLE 4: Characteristics of test piles at the hard rock bearing stratum site.

\begin{tabular}{|c|c|c|c|c|c|c|c|c|c|c|c|c|}
\hline Pile no. & 1 & 2 & 3 & 4 & 5 & 6 & 7 & 8 & 9 & 10 & 11 & 12 \\
\hline Diameter $(\mathrm{mm})$ & $\phi 500$ & $\phi 500$ & $\phi 500$ & $\phi 500$ & $\phi 500$ & $\phi 400$ & $\phi 500$ & $\phi 500$ & $\phi 400$ & $\phi 500$ & $\phi 500$ & $\phi 500$ \\
\hline Length $(\mathrm{m})$ & 22.80 & 22.80 & 25.00 & 26.00 & 25.00 & 22.00 & 25.00 & 25.00 & 22.00 & 25.00 & 25.00 & 25.00 \\
\hline Underground length $(\mathrm{m})$ & 22.50 & 22.34 & 24.85 & 25.78 & 24.82 & 22.00 & 24.50 & 24.80 & 21.85 & 24.54 & 24.00 & 24.57 \\
\hline Embedment depth of pile into rock (m) & 7.50 & 0.84 & 1.15 & 1.18 & 2.52 & 2.00 & 0.90 & 1.40 & 1.85 & 1.74 & 1.30 & 1.07 \\
\hline Grade of concrete strength & $\mathrm{C} 80$ & $\mathrm{C} 80$ & $\mathrm{C} 80$ & $\mathrm{C} 80$ & $\mathrm{C} 80$ & $\mathrm{C} 80$ & $\mathrm{C} 80$ & $\mathrm{C} 80$ & $\mathrm{C} 80$ & $\mathrm{C} 80$ & $\mathrm{C} 80$ & $\mathrm{C} 80$ \\
\hline
\end{tabular}

Note. The embedment depth of pile \#1 into rock is for fully weathered argillaceous siltstone, while that of other test piles is for highly weathered argillaceous siltstone.

TABLE 5: Average values of pile side resistance in different soil layers at the soft rock bearing stratum site.

\begin{tabular}{lccccccc}
\hline Soil layer & Filler & $\begin{array}{c}\text { Silty sand } \\
\text { (slightly dense) }\end{array}$ & $\begin{array}{c}\text { Silty sand } \\
\text { (moderately dense) }\end{array}$ & $\begin{array}{c}\text { Mucky } \\
\text { soil }\end{array}$ & $\begin{array}{c}\text { Medium } \\
\text { coarse sand }\end{array}$ & $\begin{array}{c}\text { Silty sand } \\
\text { (dense) }\end{array}$ & $\begin{array}{c}\text { Gravel } \\
\text { Highly weathered } \\
\text { mudstone }\end{array}$ \\
\hline $\begin{array}{l}\text { HSDT (kPa) } \\
\begin{array}{l}\text { Sliding micrometer } \\
\text { test }(\mathrm{kPa})\end{array}\end{array}$ & 34 & 38 & 69 & 96 & 136 & 113 & 185 \\
\hline
\end{tabular}

TABLE 6: Average values of pile side resistance in different soil layers at the hard rock bearing stratum site.

\begin{tabular}{lccccccc}
\hline Soil layer & Filler & $\begin{array}{c}\text { Silty } \\
\text { filler }\end{array}$ & $\begin{array}{c}\text { Fine } \\
\text { sand }\end{array}$ & $\begin{array}{c}\text { Mucky } \\
\text { soil }\end{array}$ & $\begin{array}{c}\text { Silty } \\
\text { clay }\end{array}$ & $\begin{array}{c}\text { Fully weathered argillaceous } \\
\text { siltstone }\end{array}$ & $\begin{array}{c}\text { Highly weathered argillaceous } \\
\text { siltstone }\end{array}$ \\
\hline $\begin{array}{l}\text { HSDT }(\mathrm{kPa}) \\
\begin{array}{l}\text { Sliding micrometer test } \\
(\mathrm{kPa})\end{array}\end{array}$ & 27 & 19 & 26 & 43 & 94 & 171 & 204 \\
\hline
\end{tabular}

TABLE 7: Values of parameter obtained from results of HSDT (at the soft rock bearing stratum site).

\begin{tabular}{|c|c|c|c|c|c|c|c|}
\hline Pile no. & 1 & 2 & 3 & 4 & 5 & 6 & Average value \\
\hline Pile end resistance $(\mathrm{kN})$ & 1310 & 788 & 850 & 1093 & 1998 & 1945 & - \\
\hline Elastic limit displacement at the end of pile ( $\mathrm{mm})$ & 11.5 & 9.3 & 10.3 & 7.2 & 7.2 & 6.9 & 8.7 \\
\hline Spring coefficient $(\mathrm{kN} / \mathrm{mm})$ & 114 & 85 & 83 & 153 & 279 & 282 & 166 \\
\hline
\end{tabular}

TABLE 8: Values of parameters achieved from the results of HSDT (at the hard rock bearing stratum site).

\begin{tabular}{lcccccccccc}
\hline Pile no. & 1 & 2 & 3 & 4 & 7 & 8 & 10 & 11 & 12 & Average value \\
\hline Pile end resistance $(\mathrm{kN})$ & 4181 & 3985 & 3422 & 2692 & 2388 & 2536 & 1784 & 2802 & 3237 & - \\
Elastic limit displacement at the end of pile $(\mathrm{mm})$ & 11.0 & 14.4 & 10.0 & 11.1 & 10.6 & 9.0 & 7.4 & 14.0 & 7.7 & 10.6 \\
Spring coefficient $(\mathrm{kN} / \mathrm{mm})$ & 380 & 277 & 342 & 242 & 225 & 282 & 241 & 200 & 420 & 290 \\
\hline
\end{tabular}

TABLE 9: Distribution of the ratio of pile side resistance to pile end resistance (at the soft rock bearing stratum site).

\begin{tabular}{|c|c|c|c|c|c|c|c|c|}
\hline \multirow{2}{*}{$\begin{array}{l}\text { Parameter } \\
\text { Pile no. }\end{array}$} & \multicolumn{4}{|c|}{ Sliding micrometer test (SLT) } & \multicolumn{4}{|c|}{ HSDT } \\
\hline & 1 & 3 & 5 & 6 & 1 & 3 & 5 & 6 \\
\hline Total resistance $(\mathrm{kN})$ & 4400 & 4800 & 5200 & 5600 & 4862 & 4635 & 4993 & 4906 \\
\hline Pile side resistance $(\mathrm{kN})$ & 3208 & 2450 & 4342 & 4098 & 3552 & 3785 & 2995 & 2961 \\
\hline Pile end resistance $(\mathrm{kN})$ & 1192 & 2350 & 858 & 1501 & 1310 & 851 & 1998 & 1945 \\
\hline Ratio of pile end resistance to total resistance & 0.27 & 0.49 & 0.17 & 0.27 & 0.27 & 0.18 & 0.40 & 0.40 \\
\hline
\end{tabular}

$-12.4 \%(7.9 \%)$, respectively. However, the differences between the results of numerical simulation and the SLTs were $9.1 \%(2.8 \%), 0 \%(9.1 \%), 0 \%(8.3 \%)$, and $-7.1 \%(0 \%)$, respectively. It is noteworthy that the calculation of vertical bearing capacity by a standard empirical formula is very conservative and the maximum error reaches $-26.9 \%$ and $-20.0 \%$ for piles at the soft rock bearing stratum site and hard one, respectively. 
TABLE 10: Distribution ratio of pile side resistance to pile end resistance (at the hard rock bearing stratum site).

\begin{tabular}{|c|c|c|c|c|c|c|c|c|}
\hline \multirow{2}{*}{$\begin{array}{l}\text { Parameter } \\
\text { Pile no. }\end{array}$} & \multicolumn{4}{|c|}{ Sliding micrometer test (SLT) } & \multicolumn{4}{|c|}{ HSDT } \\
\hline & 7 & 8 & 10 & 11 & 7 & 8 & 10 & 11 \\
\hline Total resistance $(\mathrm{kN})$ & 4282 & 4400 & 4800 & 4400 & 4463 & 5041 & 4131 & 4746 \\
\hline Pile side resistance $(\mathrm{kN})$ & 2783 & 3197 & 3068 & 2381 & 2075 & 2705 & 2347 & 1944 \\
\hline Pile end resistance $(\mathrm{kN})$ & 1499 & 1203 & 1732 & 2019 & 2388 & 2336 & 1784 & 2802 \\
\hline Ratio of pile end resistance to total resistance & 0.35 & 0.27 & 0.36 & 0.46 & 0.54 & 0.46 & 0.43 & 0.56 \\
\hline
\end{tabular}
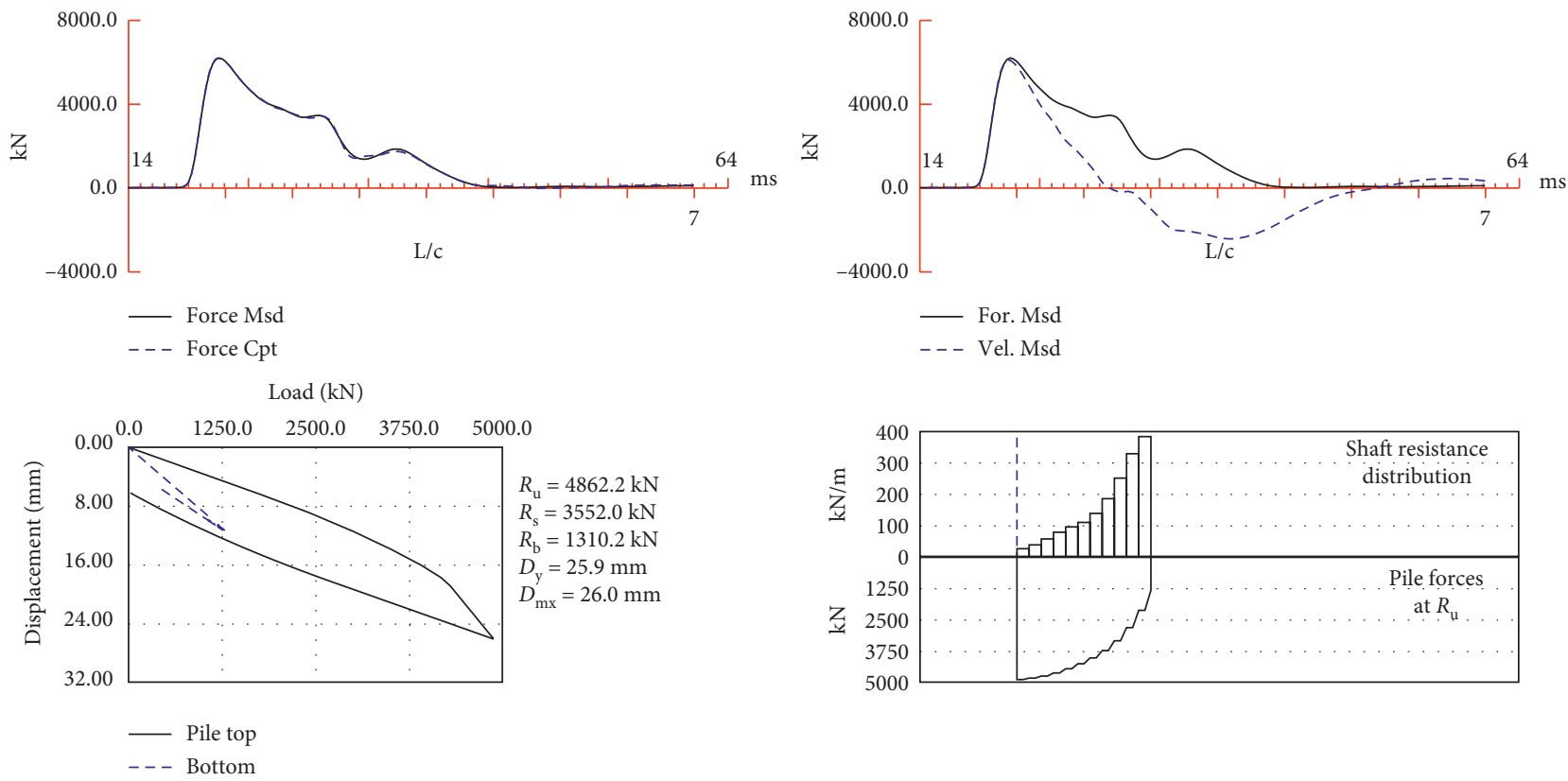

— For. Msd

- - - Vel. Msd

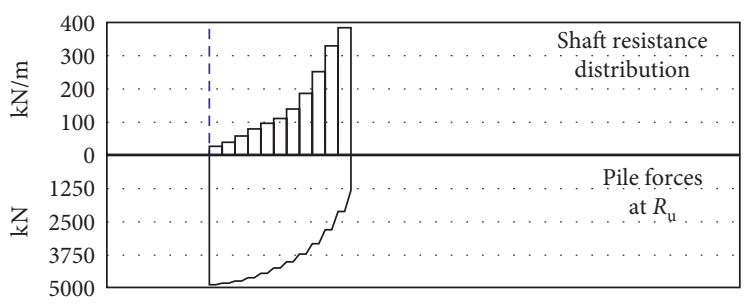

(a)
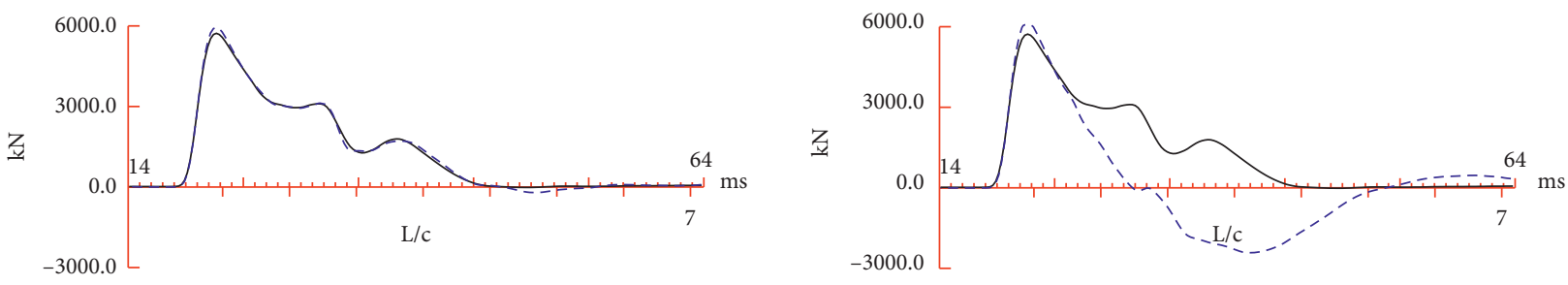

$$
\begin{aligned}
& \text { — Force Msd } \\
& --- \text { Force Cpt }
\end{aligned}
$$

Load $(\mathrm{kN})$

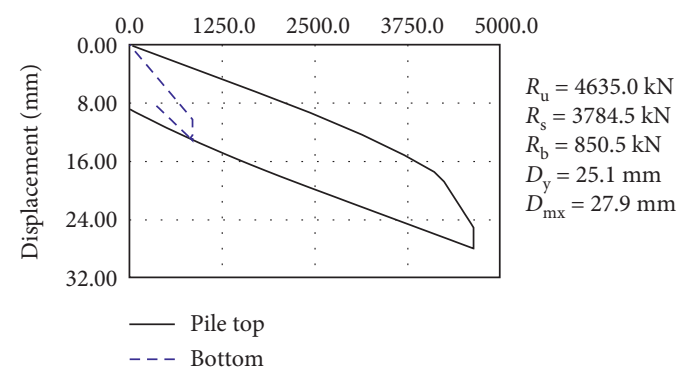

$$
\begin{array}{ll}
\hline & \text { For. Msd } \\
--- & \text { Vel. Msd }
\end{array}
$$

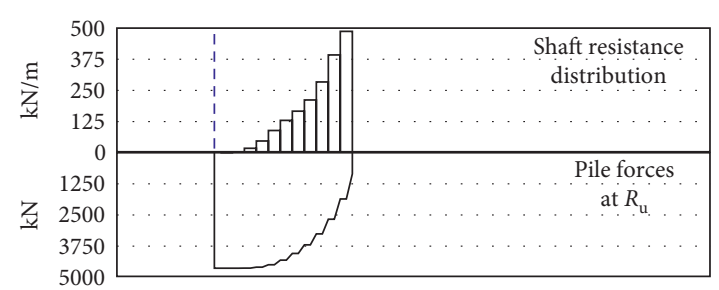

(b)

FIgURE 9: Continued. 

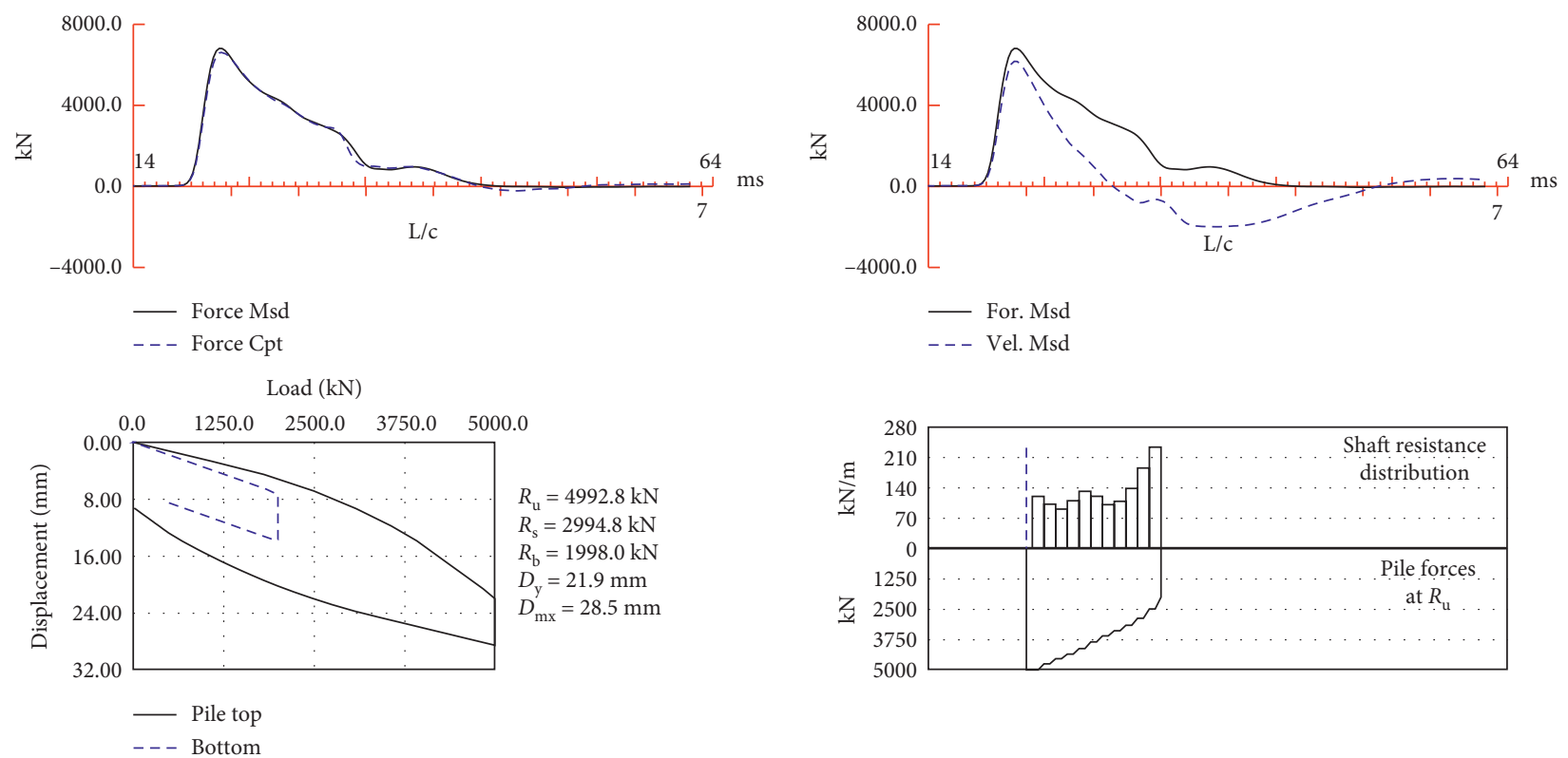

For. Msd

--- Vel. Msd

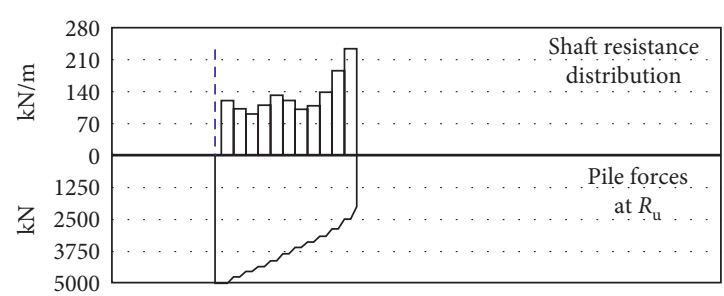

(c)
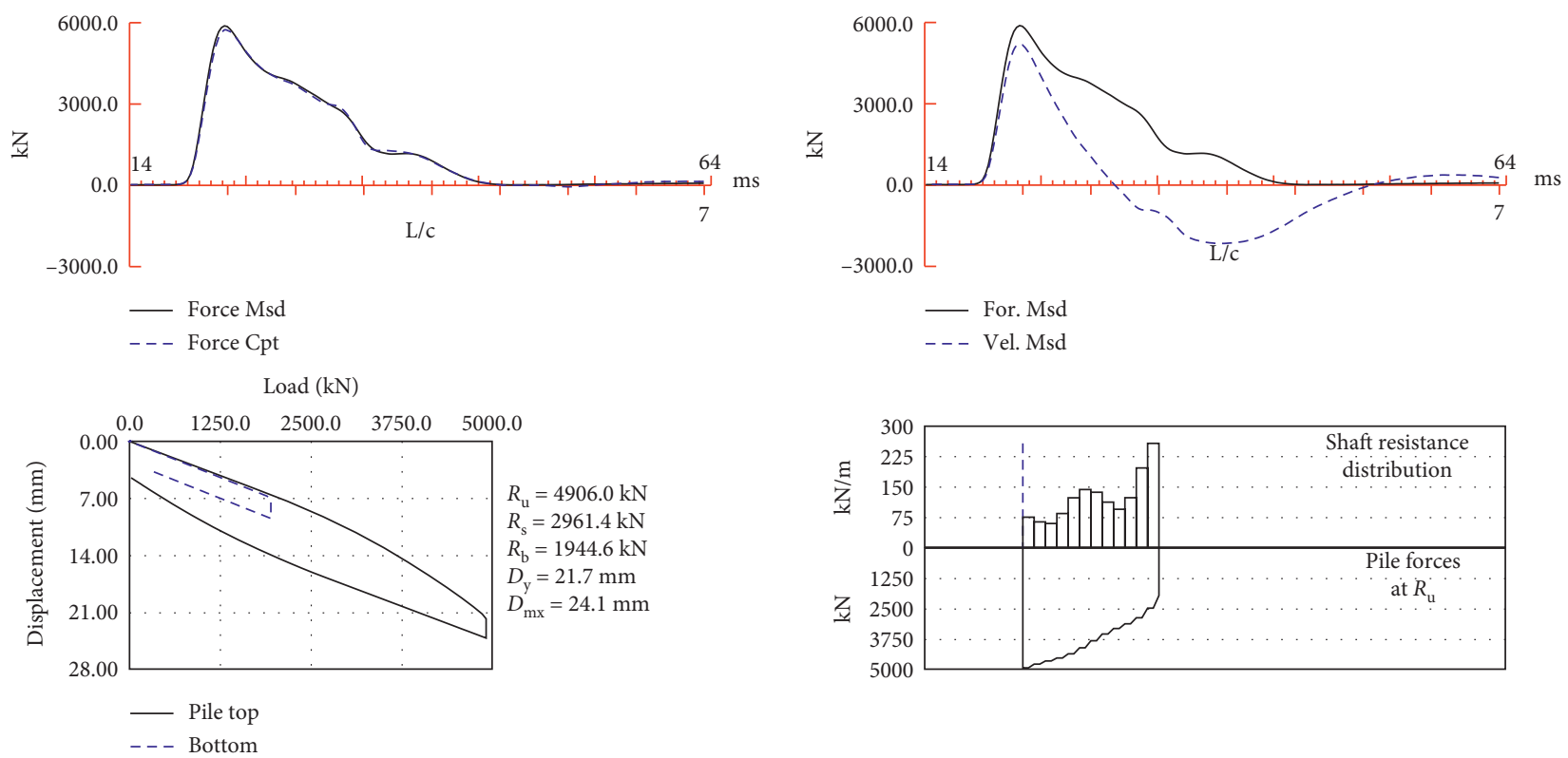

(d)

Figure 9: Results of high-strain curve fitting for test piles (at the soft rock bearing stratum site). (a) Pile \#1. (b) Pile \#3. (c) Pile \#5. (d) Pile \#6.

\section{Discussion}

The existing methods for calculating the vertical bearing capacity of prestressed pipe piles include theoretical analysis, empirical formulas, and in situ testing [22, 52-54]. However, developing a theoretical analysis has a problem that is related to difficulty in determining parameters required for calculation; besides, the use of a standard empirical formula has a problem that is related to oversimplification, resulting in conservative outcomes; in situ HSDT cannot fully simulate the vertical bearing capacity of end-bearing pile, while SLT is costly.
Compared with empirical formulas, the numerical parameters used in the proposed method are based on in situ testing data, while the numerical parameters used in empirical formulas are on the basis of empirical values or data retrieved from geotechnical tests; thus, the numerical results seem to be more reasonable in the current study. It is noteworthy that previously reported data related to geotechnical tests cannot truly reflect actual conditions of a site. In this research, the data related to pile side resistance, pile end resistance, and pile end displacement could be collected from HSDT. These data were then imported into the novel numerical method presented in this research. 

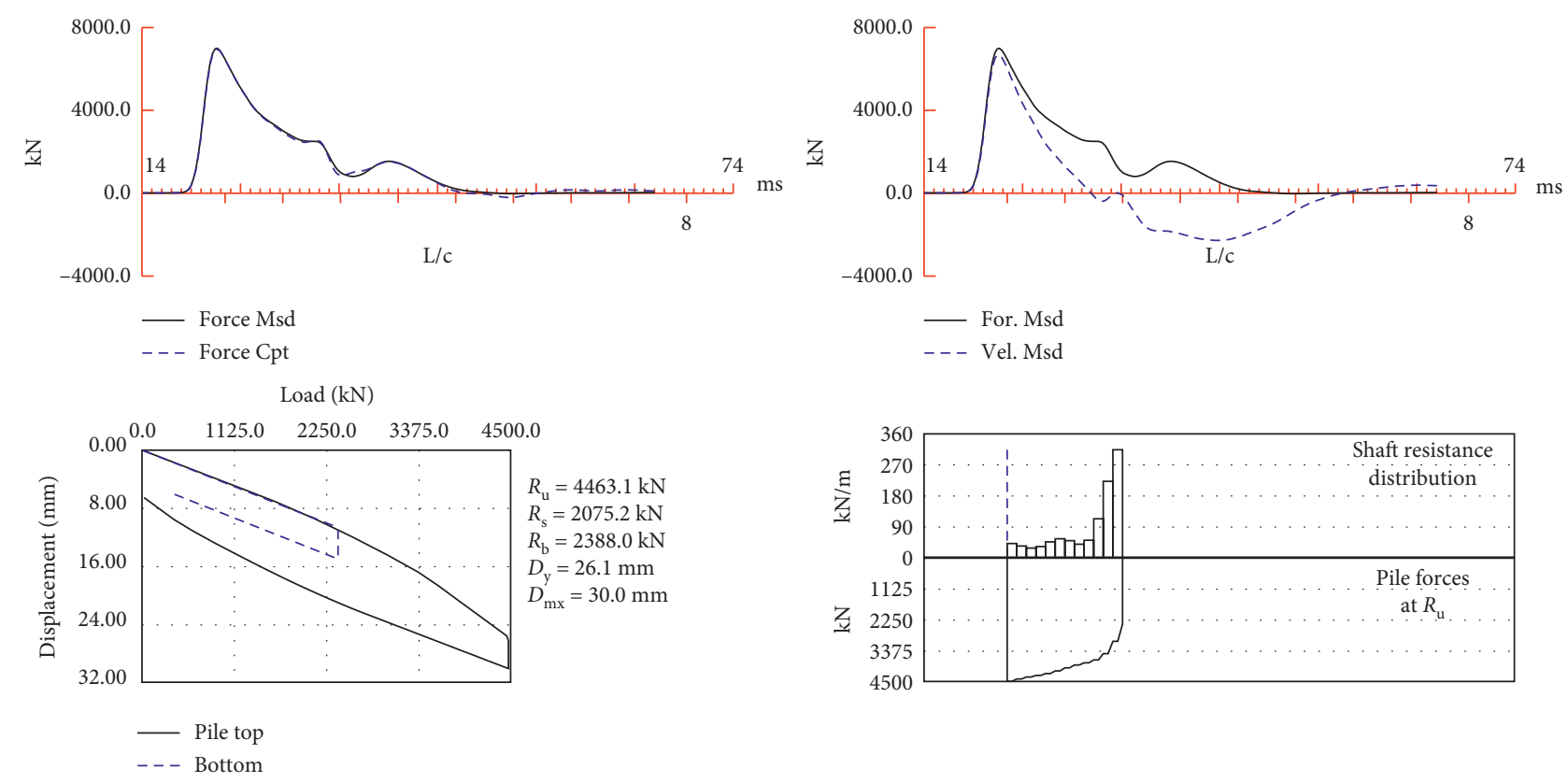

(a)
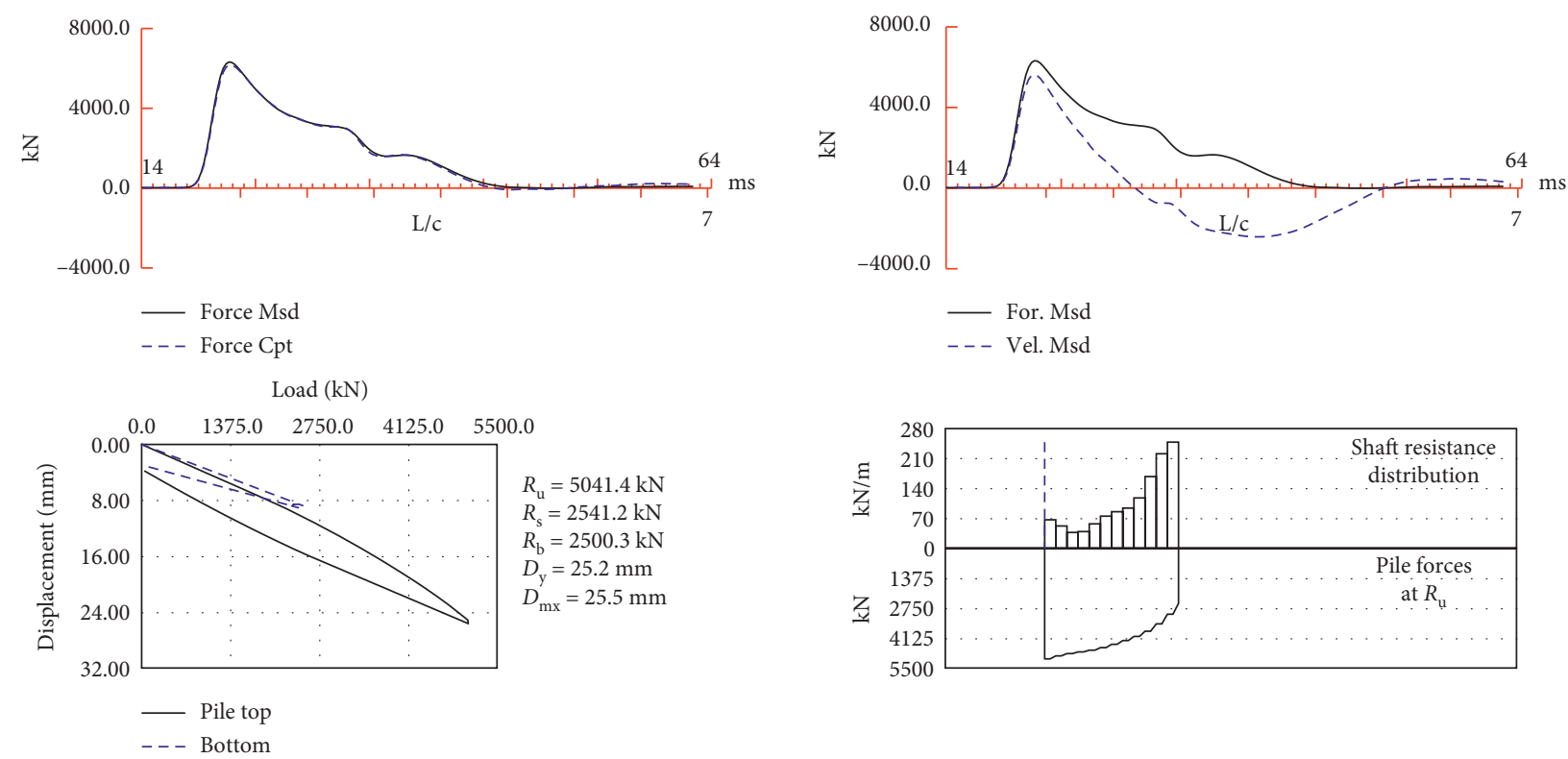

(b)

Figure 10: Continued. 

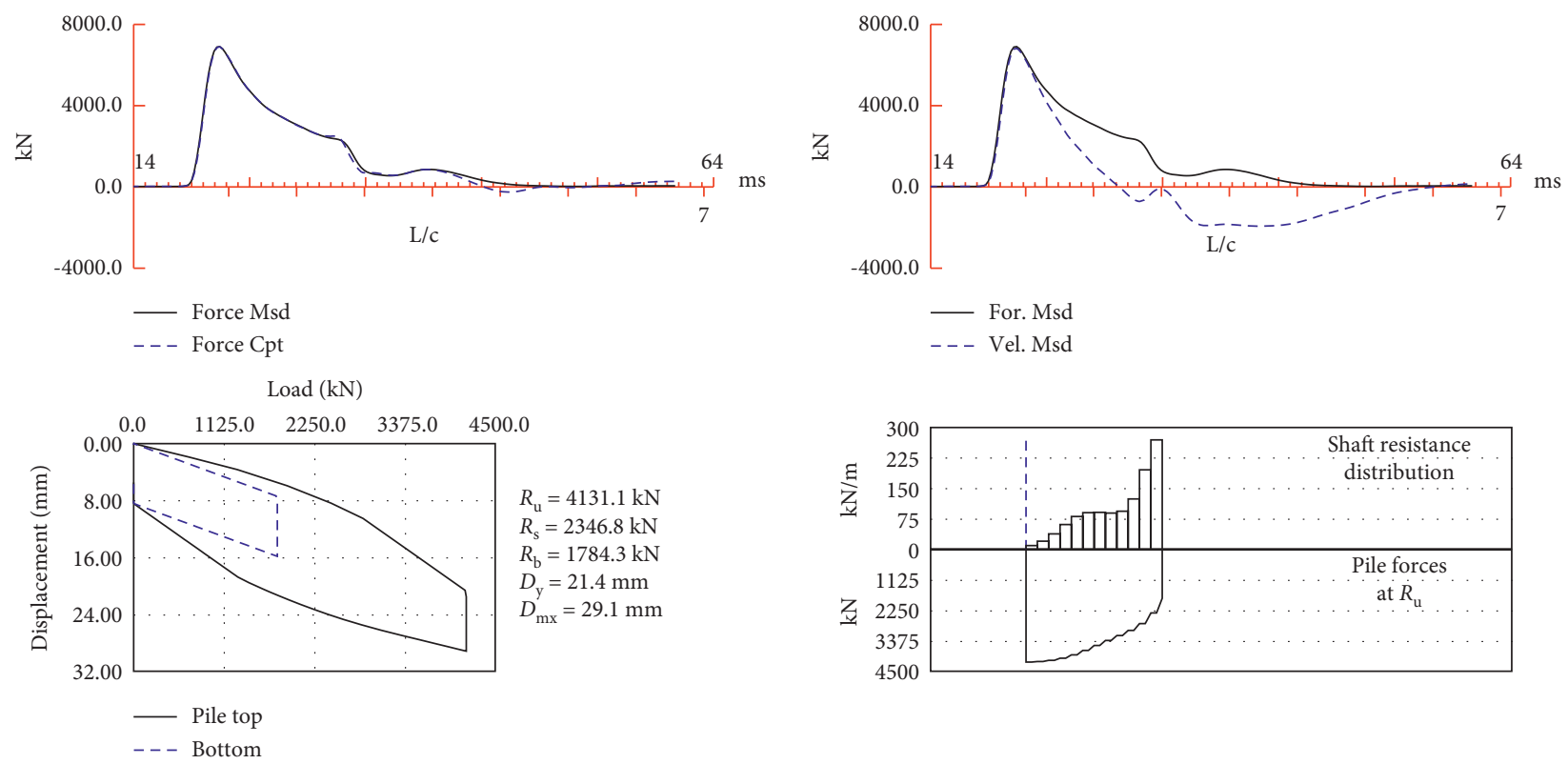

- For. Msd

- - - Vel. Msd

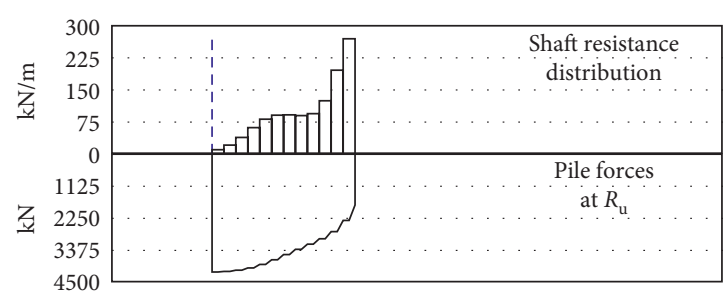

(c)
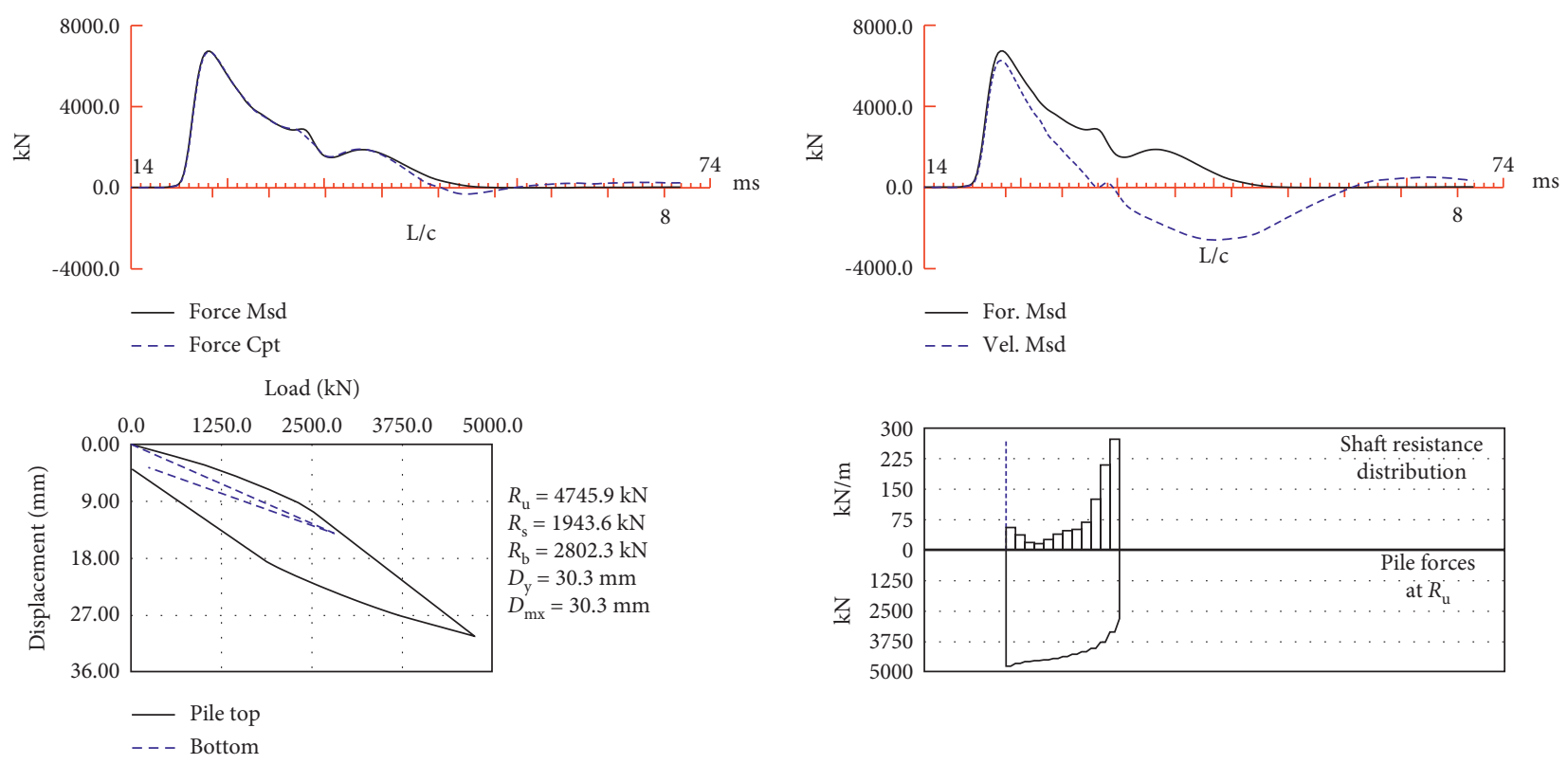

(d)

Figure 10: Results of high-strain curve fitting for test piles (at the hard rock bearing stratum site). (a) Pile \#7. (b) Pile \#8. (c) Pile \#10. (d) Pile $\# 11$.

The proposed numerical method uses the results of HSDT to indicate the pile side ultimate resistance and the pile end spring coefficient, and then, the novel model calculates the vertical ultimate bearing capacity of prestressed concrete pipe piles based on the ultimate displacement of the pile end. This process could avoid errors caused by inadequate excitation of the pile end-bearing capacity in HSDT. In addition, multiple pile observational points were used in this study to achieve more realistic results than HSDT. Thus, the developed method is more accurate than the original theoretical method, the empirical formula, and HSDT in calculating the vertical bearing capacity of prestressed pipe piles.
The results given by this method provide the same $Q-S$ curves as the SLTs showed the same pile side resistance, pile end resistance, and pile end displacement values as HSDT. Thus, the proposed method could combine the advantages of SLT and HSDT and could provide the $R_{\mathrm{b}}-S$ curve of pile end resistance and pile end displacement. Overall, there is a great potential to apply the proposed method for prediction of the bearing capacity of prestressed concrete pipe piles and analysis of bearing mechanism of prestressed concrete pipe piles in a rock bearing stratum.

The novel numerical method was applied to a typical highly weathered mudstone and a highly weathered 

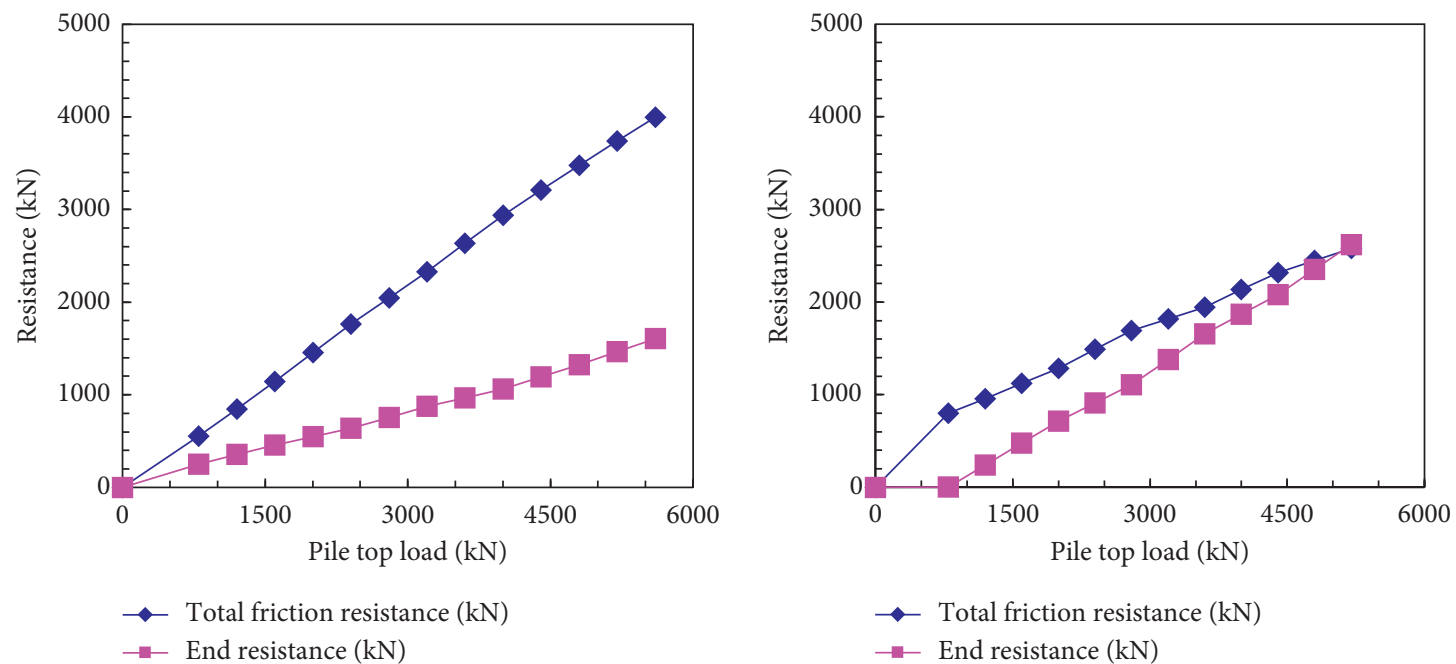

(a)

(b)

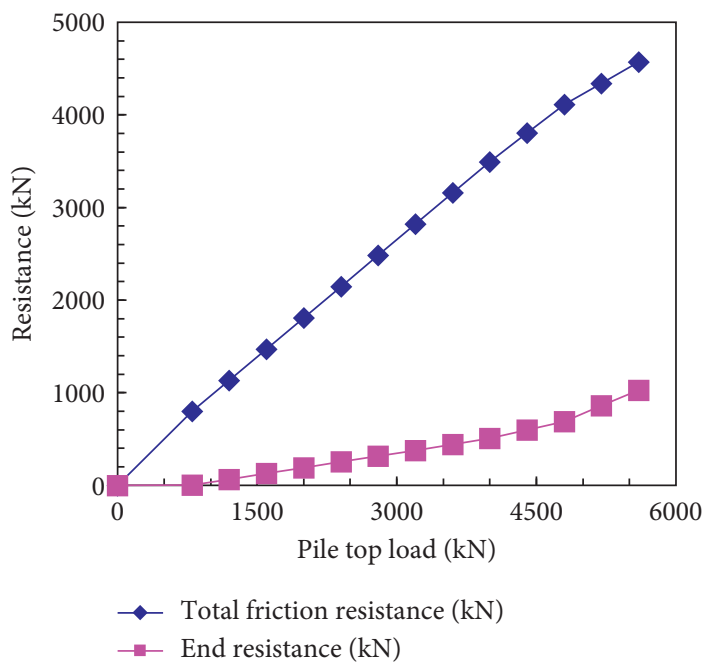

(c)

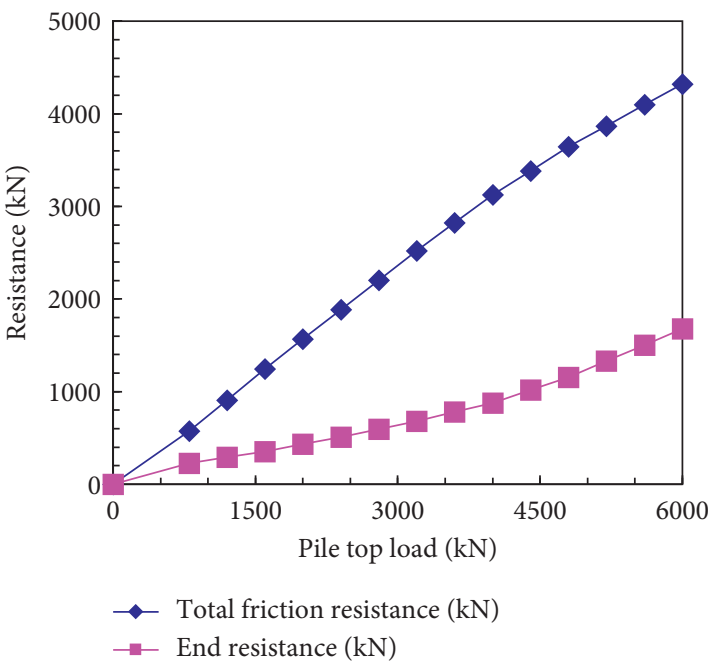

(d)

Figure 11: Illustration of relationships between total friction resistance and end resistance under various loads (at the soft rock bearing stratum site). (a) Pile \#1. (b) Pile \#3. (c) Pile \#5. (d) Pile \#6.

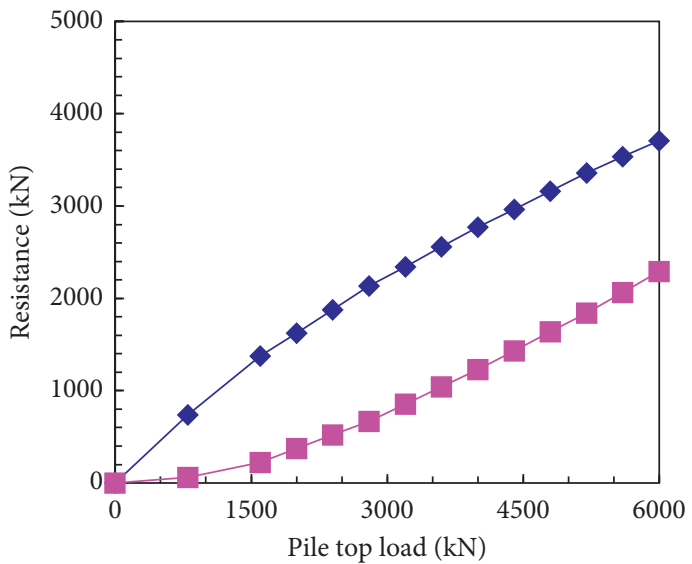

$\multimap$ Total friction resistance $(\mathrm{kN})$

$\rightarrow$ End resistance $(\mathrm{kN})$

(a)

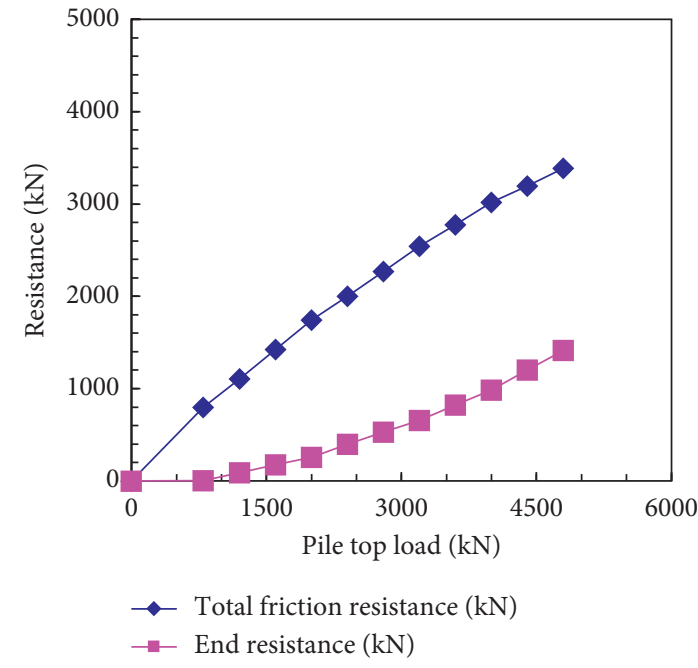

(b)

Figure 12: Continued. 


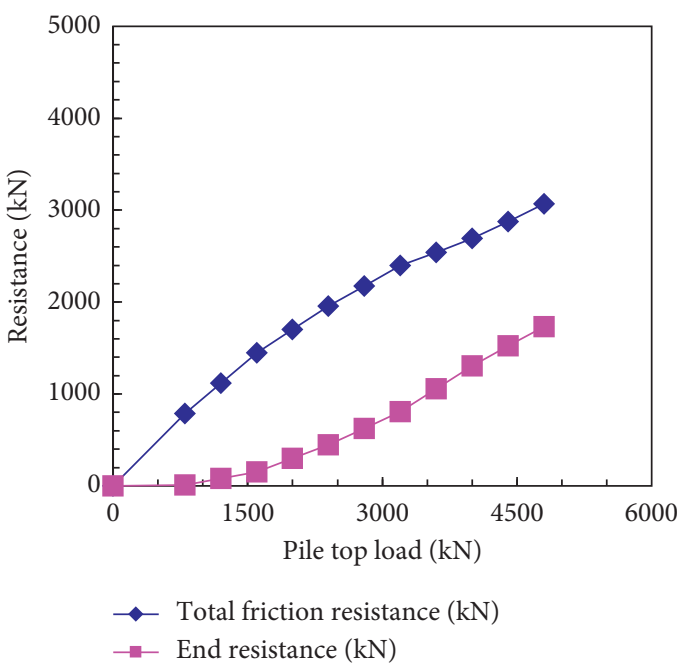

(c)

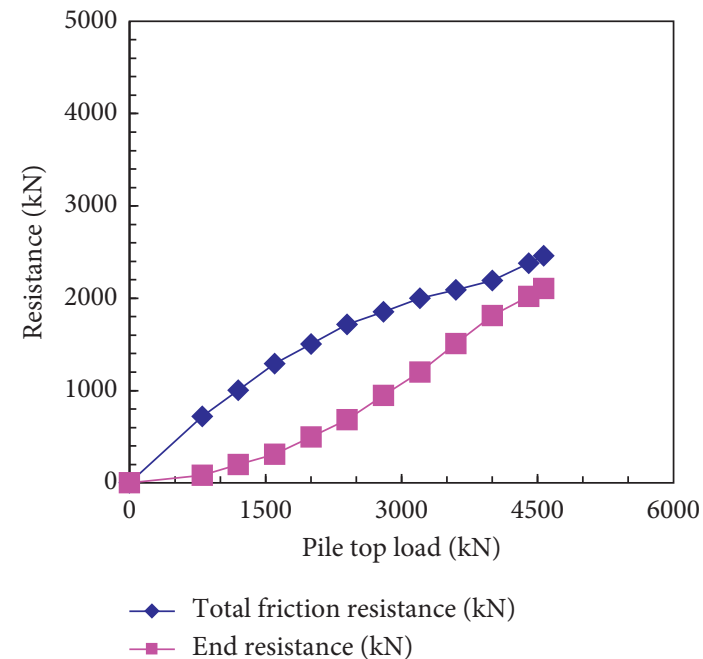

(d)

Figure 12: Illustration of relationships between total friction resistance and end resistance under various loads (at the hard rock bearing stratum site). (a) Pile \#7. (b) Pile \#8. (c) Pile \#10. (d) Pile \#11.

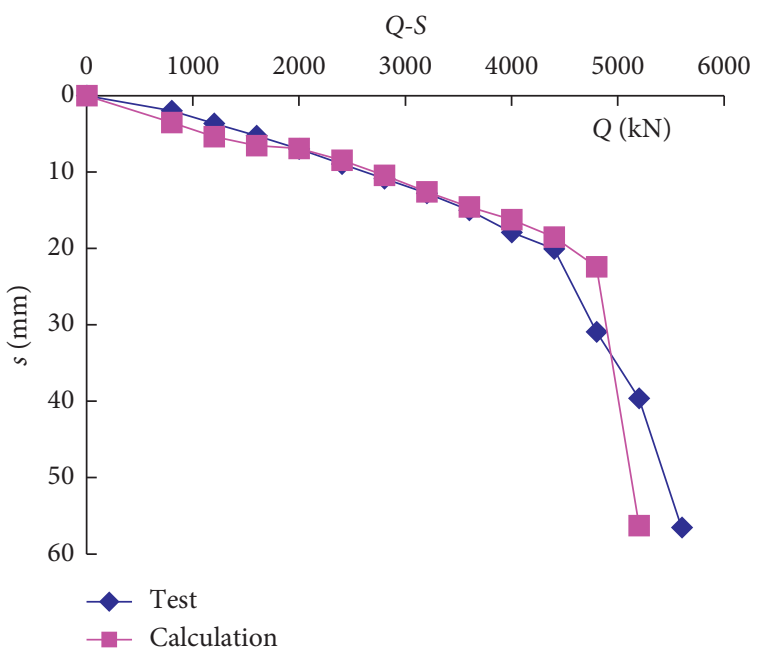

(a)

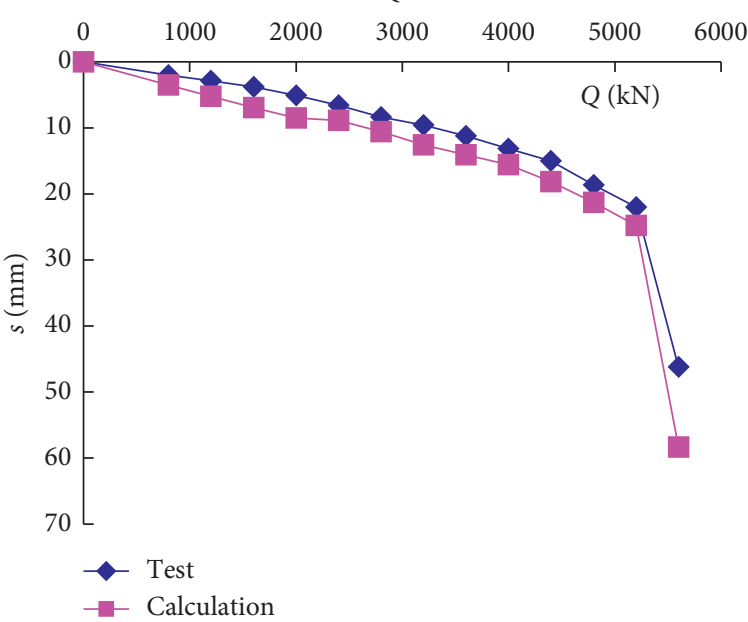

(c)

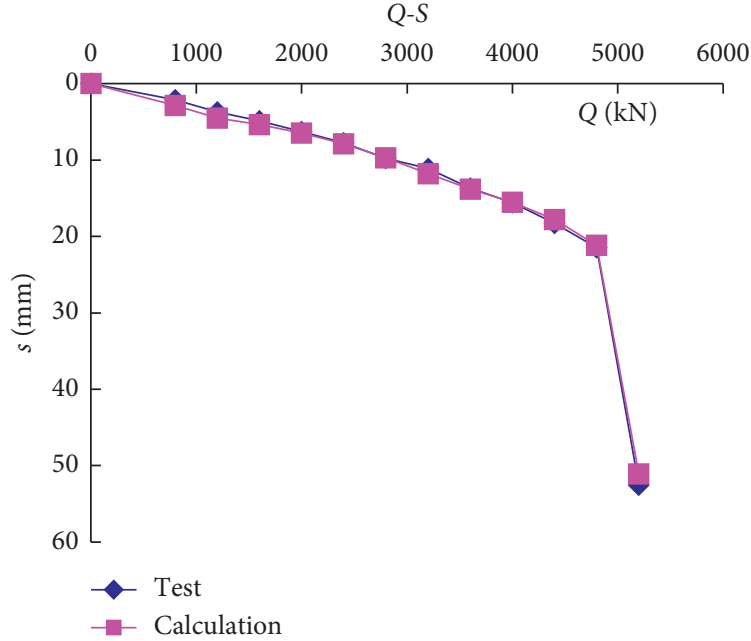

(b)

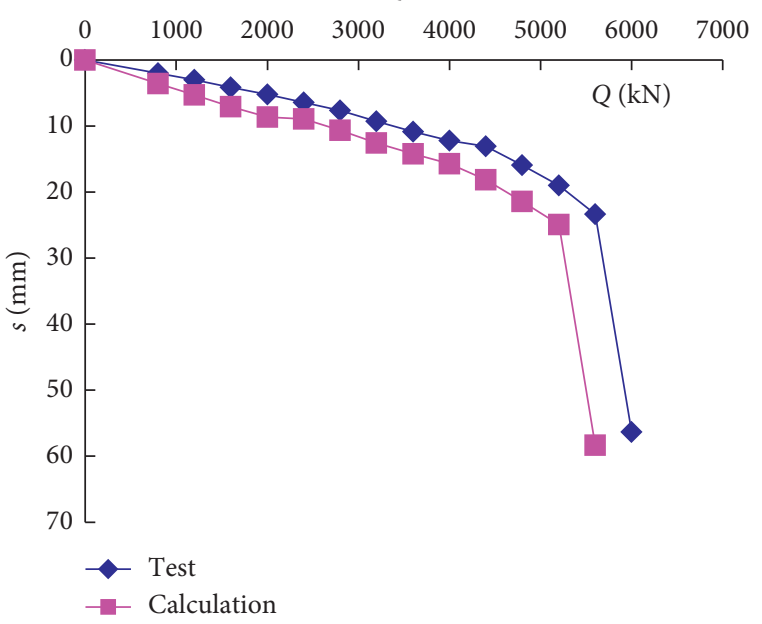

(d)

Figure 13: Comparing the results of numerical simulation and SLTs (at the soft rock bearing stratum site). (a) Pile \#1. (b) Pile \#3. (c) Pile \#5. (d) Pile \#6. 


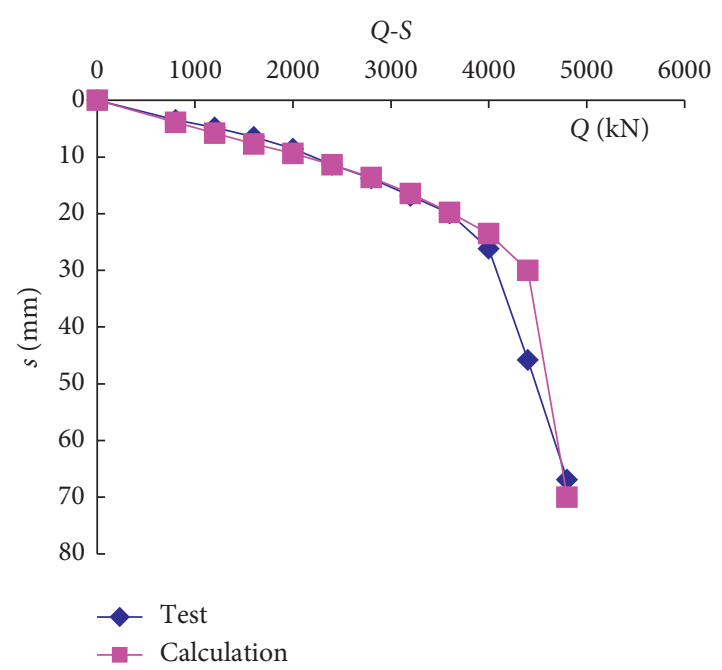

(a)

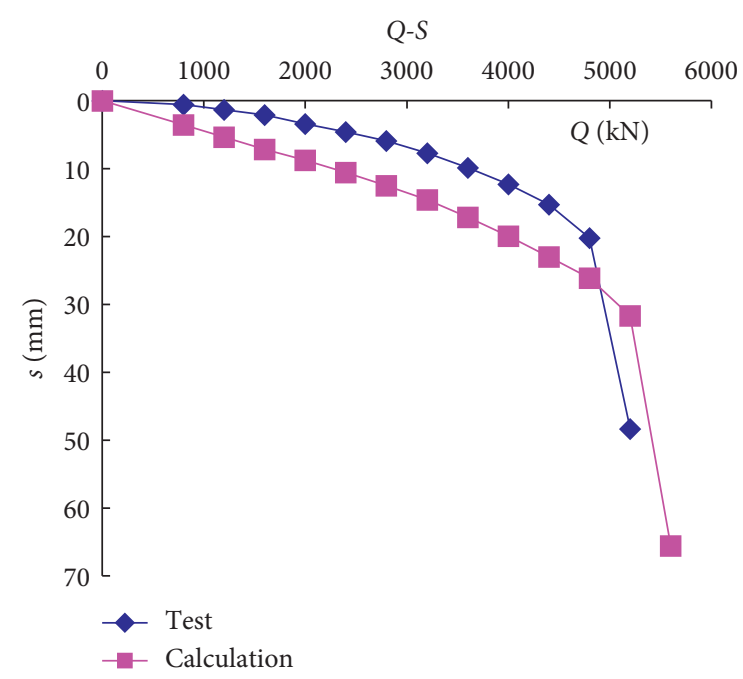

(c)

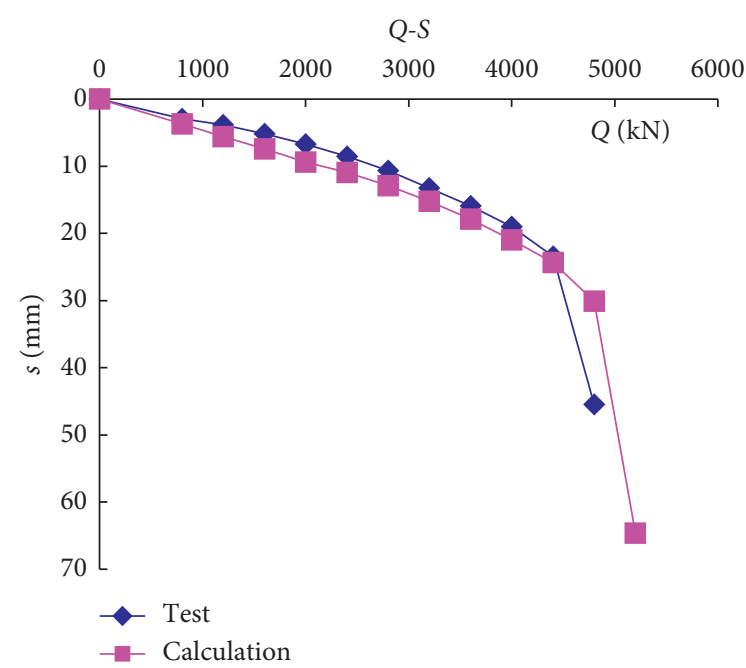

(b)

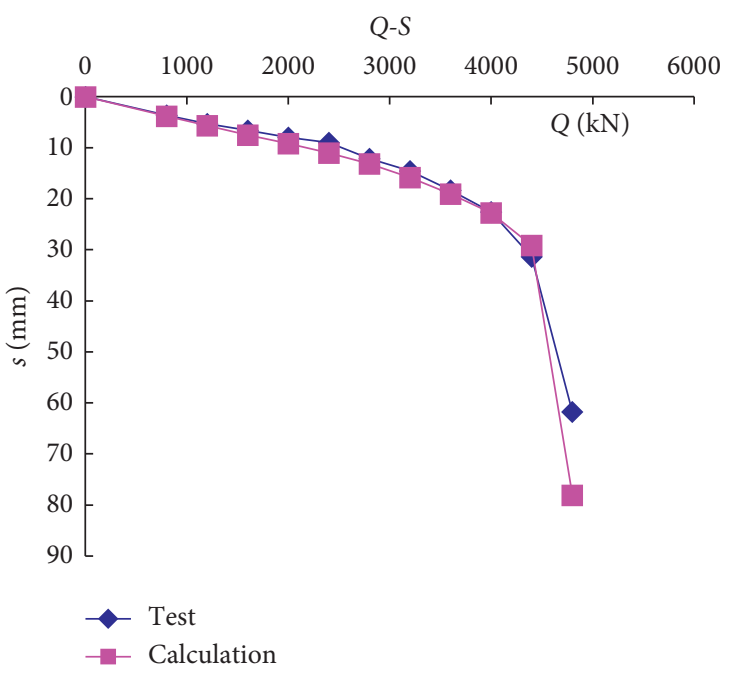

(d)

Figure 14: Comparing the results of numerical simulation and SLTs (at the hard rock bearing stratum site). (a) Pile \#7. (b) Pile \#8. (c) Pile \#10. (d) Pile \#11.

TABLE 11: Results of numerical simulation and experimental testing of test piles at the soft rock bearing stratum site.

\begin{tabular}{|c|c|c|c|c|}
\hline Pile no. & 1 & 3 & 5 & 6 \\
\hline SLT $(\mathrm{kN})$ & 4400 & 4800 & 5200 & 5600 \\
\hline $\operatorname{HSDT}(\mathrm{kN})$ & 4862 & 4635 & 4993 & 4906 \\
\hline Empirical formula $(\mathrm{kN}): R_{\mathrm{a}}=u \sum q_{\mathrm{sia}} l_{i}+q_{\mathrm{pa}} A_{\mathrm{p}}$ & 3401 & 3958 & 3918 & 4096 \\
\hline A novel numerical method $(\mathrm{kN})$ & 4800 & 4800 & 5200 & 5200 \\
\hline
\end{tabular}

TABLE 12: Results of numerical simulation and experimental testing of test piles at the hard rock bearing stratum site.

\begin{tabular}{|c|c|c|c|c|}
\hline Pile no. & 7 & 8 & 10 & 11 \\
\hline SLT $(\mathrm{kN})$ & 4282 & 4400 & 4800 & 4400 \\
\hline HSDT $(\mathrm{kN})$ & 4463 & 5041 & 4131 & 4746 \\
\hline Empirical formula $(\mathrm{kN}): R_{\mathrm{a}}=u \sum q_{\mathrm{sia}} l_{i}+q_{\mathrm{pa}} A_{\mathrm{p}}$ & 3725 & 3977 & 3838 & 3687 \\
\hline A novel numerical method $(\mathrm{kN})$ & 4400 & 4800 & 5200 & 4400 \\
\hline
\end{tabular}




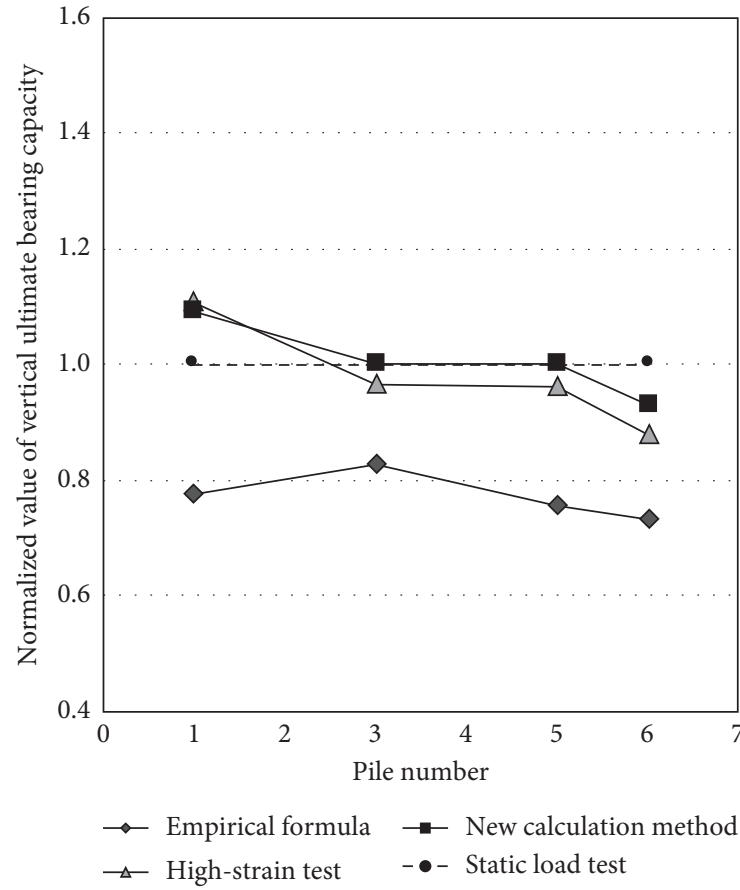

(a)

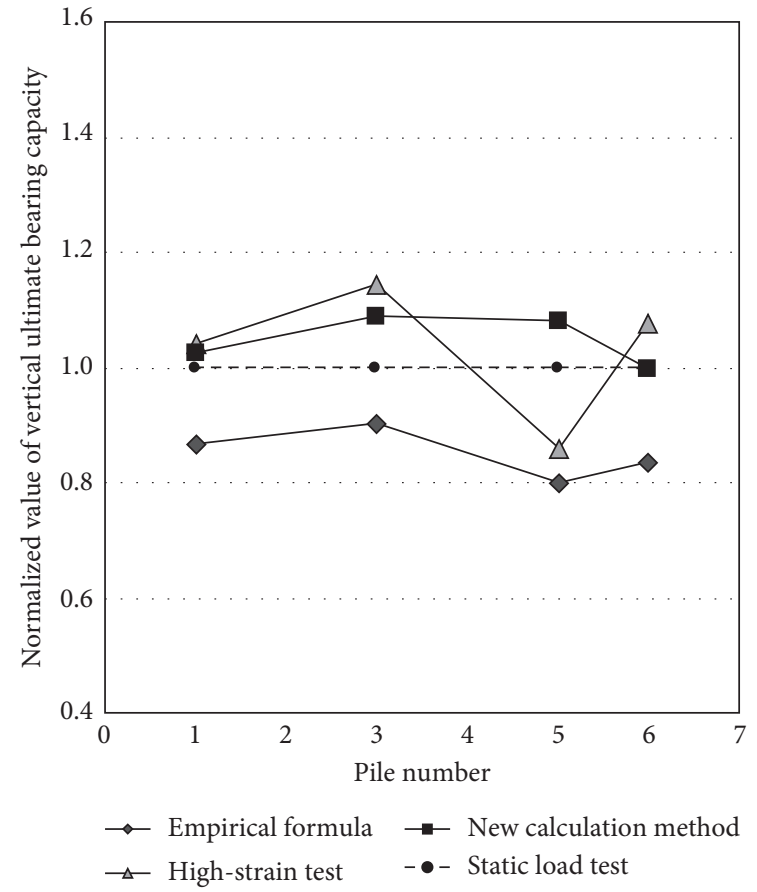

(b)

FIGURE 15: Comparison the results between different calculation methods and SLTs (normalized values) at (a) the soft rock bearing stratum site and at (b) the hard rock bearing stratum site.

argillaceous siltstone bearing stratum. Additional tests need to be carried out to determine parameters required for other typical rock bearing strata or to extract the data from previous high-strain tests, aiming to eventually establish a database. Additional research will also be required to better classify and calculate the mechanical parameters of various soil layers that surround piles.

\section{Conclusions}

In this study, a novel numerical method was developed for calculating the vertical bearing capacity of prestressed concrete pipe piles. This model was used to assess the geotechnical behavior of 20 test piles in two typical pile endbearing strata, and the numerical results were compared with those achieved by in situ testing. Thus, the following conclusions can be drawn:

(1) The results of novel numerical method were very similar to those achieved by SLT with error of within $10 \%$ compared with HSDT and empirical formulas at both soft rock bearing stratum site and hard one. The high-strain curve fitting data showed that the values of mechanical parameters, such as pile side resistance, pile end resistance, and pile end displacement were more reliable than those provided by the geotechnical testing methods, and therefore, the values of those parameter are of great practical value.

(2) High-strain curve fitting can be used to determine the parameters of pile side resistance, pile end resistance, and pile end displacement from testing of prestressed pipe piles. The standard mechanical parameters corresponding to various types of soil layers can be obtained for engineering investigation.

(3) The novel numerical method can be applied with little cost of computational resources, and thus, it can be potentially used for estimating vertical bearing capacity of prestressed pipe piles.

\section{Data Availability}

The data that support the findings of this study are available upon request from the corresponding author.

\section{Conflicts of Interest}

The authors declare that there are no conflicts of interest regarding the publication of this article.

\section{Acknowledgments}

The authors would like to thank Professor Zhangming Li for his special contributions and Guangzhou University for supporting this research. This research was supported by the National Natural Science Foundation of China (Grant no. 51908150).

\section{References}

[1] I. S. Alkroosh, M. Bahadori, H. Nikraz, and A. Bahadori, "Regressive approach for predicting bearing capacity of bored piles from cone penetration test data," Journal of Rock 
Mechanics and Geotechnical Engineering, vol. 7, no. 5, pp. 584-592, 2015.

[2] N. Zhang, M. Arroyo, M. O. Ciantia, A. Gens, and J. Butlanska, "Standard penetration testing in a virtual calibration chamber," Computers and Geotechnics, vol. 111, pp. 277-289, 2019.

[3] Y.-S. Kuo, K.-J. Chong, Y.-H. Tseng, C.-W. Hsu, and C.-S. Lin, "Assessment on liquefaction potential of sea bed soil in Chang-Bin Offshore wind farm considering parametric uncertainty of standard penetration tests," Engineering Geology, vol. 267, Article ID 105497, 2020.

[4] H. B. Seed and I. M. Idriss, "Simplified procedure for evaluating soil liquefaction potential," Journal of the Soil Mechanics and Foundations Division, vol. 97, pp. 1249-1273, 1971.

[5] S. T. G. R. Kanth and S. K. Dash, "Stochastic modeling of SPT $n$-value and evaluation of probability of liquefaction at Guwahati city," Journal of Earthquake and Tsunami, vol. 2, pp. 175-196, 2008.

[6] X. Zhang, C.-M. Lin, R. W. Dalrymple, S. Gao, and D. T. Canas, "Use of the cone penetration testing (CPT) method to interpret late quaternary tide-dominated successions: a case study from the eastern China coastal plain," Continental Shelf Research, vol. 161, pp. 49-57, 2018.

[7] A. Eslami, S. Moshfeghi, Molaabasi, and H. Eslami, "CPT and CPTu applications for DeepFoundation-bearing capacity," in Piezocone and Cone Penetration Test (CPTu and CPT) Applications in Foundation Engineering, pp. 183-231, Elsevier Butterworth-Heinemann, Oxford, UK, 2020.

[8] M. H. Baziar, A. Kashkooli, and A. Saeedi-Azizkandi, "Prediction of pile shaft resistance using cone penetration tests (CPTs)," Computers and Geotechnics, vol. 45, pp. 74-82, 2012.

[9] N. Aoki and D. De Alencar, "An approximate method to estimate the bearing capacity of piles," in Proceedings of the 5th Pan-American Conference of Soil Mechanics and Foundation Engineering, pp. 367-376, Buenos Aires, Argentina, November 1975.

[10] M. B. Clisby, R. M. Scholters, M. W. Corey, H. A. Cole, P. Teng, and J. D. Webb, An Evaluation of Pile BearingCapacities, Mississippi State Highway Department, Jackson, MS, USA, 1978.

[11] J. H. Schmertmann, "Guidelines for cone penetration test, performance and design," Report FHWA-TS-78-209, Department of Transportation, Washington, DC, USA, 1978.

[12] J. D. Kuiter and F. L. Beringen, "Pile foundations for large North Sea structures," Marine Geotechnology, vol. 3, no. 3, pp. 267-314, 1979.

[13] G. Philipponnat, "Méthode pratique de calcul d'un pieu isolé, à l'aide du pénétromètre statique," Revue Française de Géotechnique, vol. 10, no. 10, pp. 55-64, 1980.

[14] M. Bustamante and L. Gianeselli, "Pile bearing capacity prediction by means of static penetrometer CPT," in Proceedings of the 2nd European Symposium on Penetration Testing, pp. 493-500, ESOPT-II, Amsterdam, Netherlands, May 1982.

[15] M. T. Tumay and M. Fakhroo, "Friction pile bearing capacity prediction in cohesive soils using electric quasi-static penetration tests," Interim Research Report 1, Louisiana Department of Transportation and Development, Baton Rouge, LA, USA, 1982.

[16] G. Prince and I. F. Wardle, "A comparison between cone penetration test results and the performance of small diameter instrumented piles in silty clay," in Proceedings of the 2nd
European Symposium on Penetration testing, pp. 775-780, Amsterdam, Netherlands, May 1982.

[17] A. Eslami and B. H. Fellenius, "Pile capacity by direct CPT and CPTu methods applied to 102 case histories," Canadian Geotechnical Journal, vol. 34, no. 6, pp. 886-904, 1997.

[18] H. Ardalan, A. Eslami, and N. Nariman-Zadeh, "Piles shaft capacity from CPT and CPTu data by polynomial neural networks and genetic algorithms," Computers and Geotechnics, vol. 36, no. 4, pp. 616-625, 2009.

[19] F. S. Niazi and P. W. Mayne, "CPTu-based enhanced UniCone method for pile capacity," Engineering Geology, vol. 212, pp. 21-34, 2016.

[20] ASTM International, ASTMD4945-17, "Standard Test Method for High-Strain Dynamic Testing of Deep Foundations,", ASTM International, West Conshohocken, PA, USA, 2017.

[21] G. Likins and F. Rausche, "Correction of CAPWAP with static load tests," in Proceedings of the Seventh InternationalConference on Application of Stress Wave Theory to Piles, pp. 153-165, The Institute of Engineers Malaysia, Kuala Lumpur, Malaysia, August 2004.

[22] T. Xu and S. Li, "Testing study on bearing capacity of pipe piles with bearing layer of mudstone," Journal of Rock Mechanics and Engineering, vol. 123, no. 2, pp. 329-333, 2004.

[23] Q.-Q. Zhang, L.-P. Li, and Y.-J. Chen, "Analysis of compression pile response using a softening model, a hyperbolic model of skin friction, and a bilinear model of end resistance," Journal of Engineering Mechanics, vol. 140, no. 1, pp. 102-111, 2014.

[24] Q.-Q. Zhang, S.-C. Li, and L.-P. Li, "Field study on the behavior of destructive and non-destructive piles under compression," Marine Georesources \& Geotechnology, vol. 32, no. 1, pp. 18-37, 2014.

[25] G. Spagnoli, P. Scheller, and P. Doherty, "In situ and laboratory tests on a novel offshore mixed-in-place pile for oil and gas platforms," Journal of Petroleum Science and Engineering, vol. 145, pp. 502-509, 2016.

[26] A. K. Nazir and W. R. Azzam, "Improving the bearing capacity of footing on soft clay with sand pile with/without skirts," Alexandria Engineering Journal, vol. 49, no. 4, pp. 371-377, 2010.

[27] S. Jeong, J. Ko, J. Won, and K. Lee, "Bearing capacity analysis of open-ended piles considering the degree of soil plugging," Soils and Foundations, vol. 55, no. 5, pp. 1001-1014, 2015.

[28] M. Jafari, H. Gharsallaoui, K. H. Victor, and A. Holeyman, "End bearing response of open-ended pipe piles embedded in rock," International Journal of Rock Mechanics and Mining Sciences, vol. 119, pp. 46-57, 2019.

[29] E. Momeni, R. Nazir, D. Jahed Armaghani, and H. Maizir, "Prediction of pile bearing capacity using a hybrid genetic algorithm-based ANN," Measurement, vol. 57, pp. 122-131, 2014.

[30] M. A. Shahin, M. B. Jaksa, and H. R. Maier, "Artificial neural network application in geotechnical engineering," Australian Geomechanics Journal, vol. 36, pp. 49-62, 2001.

[31] M. Roosta, M. Ghaedi, A. Daneshfar, R. Sahraei, and A. Asghari, "Optimization of the ultrasonic assisted removal of methylene blue by gold nanoparticles loaded on activated carbon using experimental design methodology," Ultrasonics Sonochemistry, vol. 21, no. 1, pp. 242-252, 2014.

[32] M. Roosta, M. Ghaedi, N. Shokri, A. Daneshfar, R. Sahraei, and A. Asghari, "Optimization of the combined ultrasonic assisted/adsorption method for the removal of malachite green by gold nanoparticles loaded on activated carbon: 
experimental design," Spectrochimica Acta Part A: Molecular and Biomolecular Spectroscopy, vol. 118, pp. 55-65, 2014.

[33] M. Ghaedi, A. Ansari, M. H. Habibi, and A. R. Asghari, "Removal of malachite green from aqueous solution by zinc oxide nanoparticle loaded on activated carbon: kinetics and isotherm study," Journal of Industrial and Engineering Chemistry, vol. 20, no. 1, pp. 17-28, 2014.

[34] M. A. Shahin, "A review of artificial intelligence applications in shallow foundations," International Journal of Geotechnical Engineering, vol. 9, no. 1, pp. 49-60, 2014.

[35] M. A. Shahin, "State-of-the-art review of some artificial intelligence applications in pile foundations," Geoscience Frontiers, vol. 7, no. 1, pp. 33-44, 2016.

[36] A. Raza, A. M. Qureshi, M. Q. Saleem, and S. Maqbool, "Phagocytosis-based camera-in-situ method for pile load testing," Automation in Construction, vol. 45, pp. 33-41, 2014.

[37] Y. Chen, A. Deng, F. Lu, and H. Sun, "Failure mechanism and bearing capacity of vertically loaded pile with partiallyscrewed shaft: experiment and simulations," Computers and Geotechnics, vol. 118, Article ID 103337, 2020.

[38] Y. Cai, B. Xu, Z. Cao, X. Geng, and Z. Yuan, "Solution of the ultimate bearing capacity at the tip of a pile in inclined rocks based on the Hoek-Brown criterion," International Journal of Rock Mechanics and Mining Sciences, vol. 125, Article ID 104140, 2020.

[39] K. Józefiak, A. Zbiciak, M. Maślakowski, and T. Piotrowski, "Numerical modelling and bearing capacity analysis of pile foundation," Procedia Engineering, vol. 111, pp. 356-363, 2015.

[40] S. Teramoto, T. Niimura, T. Akutsu, and M. Kimura, "Evaluation of ultimate behavior of actual large-scale pile group foundation by in-situ lateral loading tests and numerical analysis," Soils and Foundations, vol. 58, no. 4, pp. 819-837, 2018.

[41] R. Liang and L. Yang, Dynamic Pile Testing Technology Validation and Implementation, Akron University, Akron, OH, USA, 2007.

[42] R. Salgado, Y. Zhang, G. Abou-Jaoude, D. Loukidis, and V. Bisht, "Pile driving formulas based on pile wave equation analyses," Computers and Geotechnics, vol. 81, pp. 307-321, 2017.

[43] S. Liu, "Applied research on high strain measurement of bearing capacity in the detection of pre-stressed pipe piles," MSc Thesis, Qingdao University of Technology, Qingdao, Shandong, China, 2015.

[44] J. E. Bowles, Analytical and Computer Methods in Foundation Engineering, McGraw-Hill, 1974.

[45] C. K. Wang, Matrix Methods of Structural Analysis, pp. 23-33, International Textbook, Scranton, PA, USA, 1970.

[46] H. I. Laursen, Structural Analysis, McGraw-Hill, New York, NY, USA, 1969.

[47] R. Chen and R. L. Wang, "Analysis and treatment of the bearing capacity behavior of sloping pre-stressed pipe pile," Chinese Journal of Rock Mechanics and Engineering, vol. 25, no. S2, pp. 3545-3551, 2006.

[48] R. Sato, "Bearing capacity mechanism of foundation pile," Civil Technology, vol. 20, no. 1, pp. 1-5, 1965.

[49] R. Chen, J. Zhang, J. Chen, W. Hu, K. Xiong, and B. L. Cheng, "Study on bearing mechanism of pelitic prestressed pipe pile based on in-situ test," Guangdong Architecture Civil Engineering, vol. 25, no. 10, pp. 6-10, 2018.

[50] H. Luo and G. Li, "Unified three-fold line model of load transfer function and its verification," Highway Traffic
Research (Application Technology Edition), vol. 12, no. 4, pp. 256-261, 2016.

[51] L. M. Kraft, R. P. Ray, and T. Kagawa, "Theoretical t-z curves," Journal of the Geotechnical Engineering Division, vol. 107, no. 11, pp. 1543-1561, 1981.

[52] D.-D. Pan, Q.-Q. Zhang, S.-W. Liu, and S.-M. Zhang, "Analysis on response prediction of a single pile and pile groups based on the Runge-Kutta method," KSCE Journal of Civil Engineering, vol. 22, no. 1, pp. 92-100, 2018.

[53] G. Fu, L. Wei, and H. Zhou, "A modified shear displace method for calculating settlement of single pile," Advanced Materials Research, vol. 261263, pp. 1804-1808, 2012.

[54] Y. Wei, D. Wang, J. Li et al., "Evaluation of ultimate bearing capacity of pre-stressed high-strength concrete pipe pile embedded in saturated sandy soil based on in-situ test," Applied Sciences, vol. 10, no. 18, p. 6269, 2020. 